\title{
Influence of shallow-water habitats and shoreline development on abundance, biomass, and diversity of benthic prey and predators in Chesapeake Bay
}

\author{
R. D. Seitz ${ }^{*}$, R. N. Lipcius, N. H. Olmstead, M. S. Seebo, D. M. Lambert \\ Virginia Institute of Marine Science, The College of William and Mary, PO Box 1346, Gloucester Point, Virginia 23062, USA
}

\begin{abstract}
Within the coastal zone, waterfront development has caused severe loss of shallowwater habitats, such as salt marshes and seagrass beds. Although the effects of habitat degradation on community structure within intertidal marshes have been well studied, little is known about the impact of habitat degradation on, and the ecological value of, subtidal shallow-water habitats, despite the prevalence of these habitats in coastal ecosystems. In coastal habitats, bivalves are dominant benthic organisms that can comprise over $50 \%$ of benthic prey biomass and are indicative of benthic production. We quantified bivalve diversity, density, and biomass in deep and shallow ( $<1.5 \mathrm{~m}$ MLW) unstructured subtidal habitats in 2 tributaries of lower Chesapeake Bay (ElizabethLafayette River system and York River). We also examined the effects of shoreline alteration in shallow habitats by contrasting the benthos of the subtidal areas adjacent to natural marsh, bulkhead, and rip-rap shorelines. Bivalve diversity, density, and biomass were significantly higher in shallow than in deep benthic habitats in both systems. Benthic abundance and diversity were higher in subtidal habitats adjacent to natural marsh than those adjacent to bulkhead shorelines; abundance and diversity were intermediate in rip-rap shorelines, and appeared to depend on landscape features. Predator density and diversity tended to be highest adjacent to natural marsh shorelines, and density of crabs was significantly higher in natural marsh than in bulkhead habitats. There is thus a crucial link between natural marshes, infaunal prey in subtidal habitats, and predator abundance. Consequently, the indirect effects of coastal habitat degradation upon secondary production in the shallow, subtidal habitats adjacent to salt marshes may be as great as or greater than direct habitat effects.
\end{abstract}

KEY WORDS: Shallow-water habitats - Shoreline development - Bivalves · Macoma balthica . Callinectes sapidus $\cdot$ Chesapeake Bay $\cdot$ Food web $\cdot$ Benthos

Resale or republication not permitted without written consent of the publisher

\section{INTRODUCTION}

In Chesapeake Bay, coastal areas are characterized by vast expanses of unvegetated sand and mud habitats that harbor important infaunal communities. Such communities serve critical ecosystem functions (e.g. nutrient cycling) and provide food for epibenthic predators including the blue crab Callinectes sapidus and various demersal fishes (Horwitz 1987, Diaz \& Schaffner 1990, Hines et al. 1990, Seitz et al. 2001, 2003b). For instance, infaunal clams in these communities comprise the highest percentage, up to $55 \%$, of the blue crab diet (Laughlin 1982, Hines et al. 1990, Mansour \& Lipcius 1991, Mansour 1992).

Bivalves are dominant and representative members of healthy Chesapeake Bay benthic communities and are typically a long-lived, key component of the benthos, sometimes comprising up to $90 \%$ of the benthic prey biomass (Hagy 2002); many species are considered estuarine endemics or residents (Boesch 1977, Holland 1985). Whereas bivalves such as clams, oysters, and mussels often dominate 'biomass' of benthic communities, annelids may dominate 'numbers' of organisms in these systems, depending on location, 
habitat, and season (Boesch 1977, Virnstein 1977, Hines et al. 1990, Dauer 2001, Hagy 2002). Chesapeake Bay infaunal bivalve assemblages include major species such as the Baltic macoma Macoma balthica, the hard clam Mercenaria mercenaria, and the stout razor clam Tagelus plebeius (Boesch 1977, Holland 1985). Polychaetes sometimes comprise a substantial fraction of benthic prey biomass (Diaz \& Schaffner 1990, Dauer 2001, Schaffner et al. 2002), especially in polyhaline (18 to $30 \mathrm{psu}$ ) reaches of the bay where euryhaline opportunists are common (Boesch 1977).

Benthic species diversity can vary in concert with the intensity of competition, predation, disturbance, and environmental gradients (Paine 1966, Virnstein 1977, Connell 1978, Sih et al. 1985). In Chesapeake Bay, for example, diversity of infauna is positively correlated with salinity (Boesch 1977). Stable environmental conditions often result in higher diversity, as in the tropics where fluctuations in temperature and other environmental factors are minimal and diversity is high (Jackson 1972, Virnstein et al. 1984, Rex et al. 1993). Moreover, benthic diversity and abundance can be indicative of habitat quality and may signify which habitats are productive in the ecosystem (Dauer et al. 2000).

In shallow tributaries of Chesapeake Bay, shallowwater benthic prey biomass is high and can lead to elevated densities of consumers (i.e. bottom-up control; Seitz et al. 2003b), suggesting that these habitats are at least as productive as deep-water habitats, if not more so. The notion that most benthic prey biomass is in deep soft-sediment habitats is a fundamental assumption of food web models for Chesapeake Bay (Baird \& Ulanowicz 1989), and one that critically determines the output of such models. Thus, examination of this assumption is essential to the accurate portrayal of food web dynamics in estuarine systems such as Chesapeake Bay. Consequently, we conducted an extensive comparative study to quantify the abundance, biomass, and diversity of dominant benthic bivalves in both deep and shallow soft sediments of 2 tributary systems of lower Chesapeake Bay: (1) the Elizabeth-Lafayette River system (hereafter E-L) and (2) the York River (hereafter YR) (see Fig. 1). We sampled during 1 time frame because we focused on densities of the larger, longer-lived adults that have long turnover times. In addition to bivalves, we examined the total benthic community for the shoreline study in the YR to evaluate whether our bivalve associations with shoreline development extended to the infaunal community.

Both natural processes and anthropogenic activity have caused habitat loss or degradation (Seneca \& Broome 1992, Thayer 1992, Zedler 1992, Zimmerman 2000), which diminishes secondary production in affected coastal habitats. Human expansion requires that some areas of land or water be developed, causing habitat alterations and severe degradation of marine resources (Dauer 2001, Peterson \& Lipcius 2003). Despite the significance of this issue, there is a dearth of information on the impact of shoreline development and the resultant habitat degradation upon benthic and fishery production. This paucity of information has made it difficult to identify the optimal habitats for protection or restoration efforts aimed at minimizing loss of ecosystem production (Peterson \& Lipcius 2003). Moreover, although benthic prey biomass and secondary production in deep-water, soft-bottom sediments have been documented (Dauer \& Alden 1995, Weisberg et al. 1997, Dauer et al. 2000, Hagy 2002, Schaffner et al. 2002), the comparative benthic biomass in shallow-water subtidal habitats influenced by shoreline development and habitat degradation has not been quantified.

While various studies have addressed invertebrate use of intertidal marshes (Kneib et al. 1980, Kneib 1997, Cicchetti 1998, Cicchetti \& Diaz 2000, Whaley \& Minello 2002, Jivoff \& Able 2003, Minello et al. 2003, Clark et al. 2004), to our knowledge only 1 published study has explicitly addressed the effects of shoreline development on subtidal benthos (Weis et al. 1998), though some pollution studies may mention indirect effects. Weis et al. (1998) demonstrated that chemically treated, wooden bulkhead structures reduced adjacent benthic biomass and diversity compared to reference sites away from the bulkhead.

In estuarine systems, shoreline alteration and benthic community resources have been studied at larger spatial scales, though they have not been examined for the smaller-scale specific shoreline effects. For example, King et al. (2005) examined regional-scale watershed land use, suggesting that shoreline marshes are important for bivalves, and Tourtellotte \& Dauer (1983) detected depauperate benthos in the vicinity of a system with extensive bulkheading (Linkhorn Bay). A few studies also have reported negative effects of altered shorelines on predators in adjacent waters (Hendon et al. 2000, Peterson et al. 2000, Carroll 2003), but they have not concurrently examined infauna.

The abundance and diversity of epibenthic predators can vary by location, season, and environmental condition. Predator density can be related to prey density, as shown in various studies demonstrating bottom-up control (Menge et al. 1996, Seitz et al. 2003b, Posey et al. 2005) and based on the theory of ideal-free distribution (Bernstein et al. 1999). We therefore examined the effects of shoreline development upon the benthic community and epibenthic predators in shallow subtidal areas of the E-L River system and the YR. 


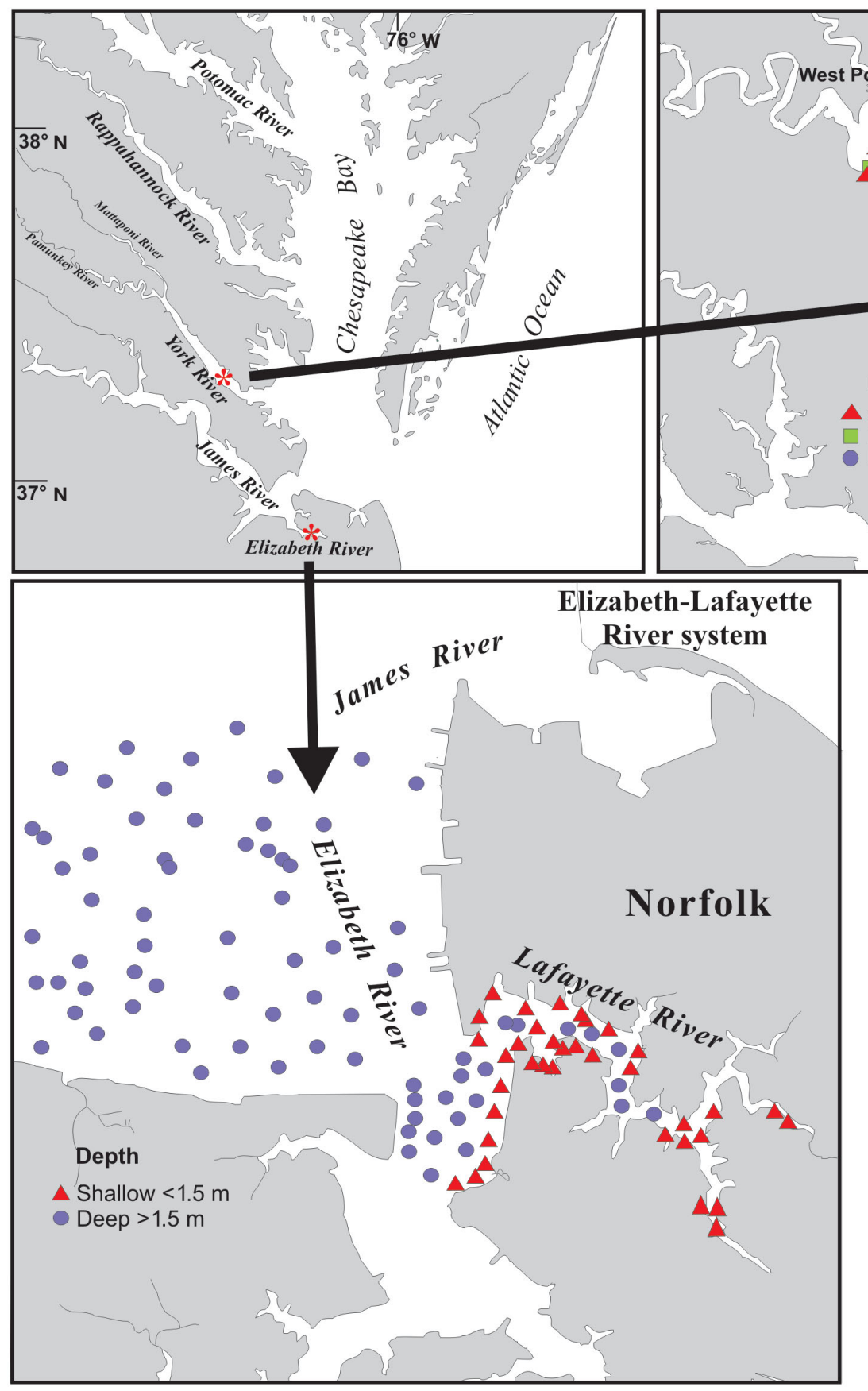

Fig. 1. Sampling sites in 2 tributary systems of the lower Chesapeake Bay (top, left panel; $\left.37^{\circ} 00^{\prime} \mathrm{N}, 76^{\circ} 50^{\prime} \mathrm{W}\right)$. Asterisks (*) show locations of areas enlarged in top right and bottom panels. Along the York River (top, right panel), sampling was conducted at shallow, mid, and deep sites on 26 September 2002. In the ElizabethLafayette River system (bottom panel), shallow sampling was conducted from 17 to 19 September 2002 and deep sampling from 23 to 25 September 2002. All depth data are given in $\mathrm{m}$ MLW

Our objectives were 2-fold. First, we aimed to assess whether there was a significant difference in density, biomass, abundance, and diversity of bivalves in shallow $(<1.5 \mathrm{~m}$ mean low water [MLW]) versus deep $(\geq 1.5 \mathrm{~m} \mathrm{MLW}$ ) habitats in the E-L River system and YR. From these data, we used the mean density and biomass within each tributary factored with bathymetry and areal coverage of shallow and deep depth strata to estimate overall abundance of organisms within each stratum. Second, we determined whether there was a significant difference in subtidal bivalve abundance, diversity, and biomass in the Lafayette River, and infaunal community diversity and abundance in the YR among shallow subtidal habitats adjacent to 3 types of shoreline developed to different degrees: (1) natural marsh, (2) rip-rap (rocks placed on a slope for erosion control), and (3) bulkhead shoreline (2 and 3 are revetments). We also estimated concurrent epibenthic predator density and diversity adjacent to the 3 shoreline types. 
Table 1. Mean $( \pm \mathrm{SE})$ values for temperature $\left(\mathrm{Temp},{ }^{\circ} \mathrm{C}\right)$, salinity (psu), \% sand, and dissolved oxygen (DO $\mathrm{mg} \mathrm{l}^{-1}$ ) at deep vs. shallow sites in the Elizabeth-Lafayette (E-L) River system (26 to 39 samples per stratum) and York River (YR) (10 to 20 samples per stratum)

\begin{tabular}{|llcccc|}
\hline & Site type & Temp & Salinity & $\%$ sand & DO \\
\hline E-L Deep & $25.1(0.1)$ & $21.9(0.9)$ & $26.7(3.4)$ & $5.6(0.2)$ \\
& Shallow & $26.6(0.1)$ & $18.5(0.4)$ & $46.2(7.4)$ & $8.4(0.5)$ \\
YR & Deep & $23.8(0.3)$ & $21.8(0.6)$ & $11.9(7.5)$ & $9.7(1.0)$ \\
& Shallow & $23.1(0.1)$ & $20.9(0.3)$ & $31.4(6.4)$ & $9.6(1.1)$ \\
\hline
\end{tabular}

\section{MATERIALS AND METHODS}

Site selection. GIS-based maps of coastal shorelines were used to delineate the areas of the deep and shallow waters of the E-L River system and the YR (Fig. 1). From the GIS-delineated strata, we used a randomnumber program to generate 121 possible random, independent sites in deep water (>1.5 m MLW) and 60 random sites in shallow water $(<1.5 \mathrm{~m} \mathrm{MLW})$ in the E-L. Of the potential sites in each stratum, we sampled 81 deep sites (mean depth $+\mathrm{SE}, 5.02+0.38 \mathrm{~m}$ ) and 40 shallow subtidal sites (mean depth $0.73+0.01 \mathrm{~m}$ ) in the E-L system. The design was unbalanced because a concurrent project required a detailed examination of bivalves in the deep waters, thus, requiring more samples there. In the YR (Fig. 1), we randomly chose 10 sites within each of 3 depth strata: (1) shallow $(<1.5 \mathrm{~m})$, (2) mid (1.5 to $3.0 \mathrm{~m})$, and (3) deep (>3 m) water. The resulting mean $( \pm \mathrm{SE})$ depths sampled were shallow $=$ $1.5 \pm 0.1 \mathrm{~m}$, mid $=2.6 \pm 0.14 \mathrm{~m}$, and deep $=8.5 \pm 0.92 \mathrm{~m}$. These sites were dispersed among the following 3 river locations: downriver (near the river mouth); center; and upriver (near the river head). This area has a semidiurnal tide of about $2 \mathrm{~m}$ range.

Within the E-L River system, shallow sampling was conducted from 17 to 19 September 2002 (along with shoreline sampling), and deep sampling was conducted from 23 to 25 September 2002. In the YR, shallow, mid, and deep sampling was conducted on 26 September 2002, a gear comparison study was conducted on 26 September 2002, and shoreline sampling was conducted from June to August 2002.

Physical variables and benthic prey collections. Water temperature, salinity, and dissolved oxygen (DO) were assessed at most of the sites; when sites were in close proximity, physical variables were only measured at 1 site (Table 1). We also took $2.5 \mathrm{~cm}$ diameter surface sediment cores for grain-size analysis. In the E-L River system, 26 to 30 samples per stratum were used for the grain-size comparisons, whereas 10 to 20 samples per stratum from the York River were used (Table 1). The percentages of gravel (>2 mm), sand (>62.5 $\mu \mathrm{m})$, silt (4 phi) and clay ( 8 phi) in sediments were determined by standard wet sieve and pipette analysis (Folk 1980; phi $=-[\ln ($ particle diameter) $\left.\left.\times \ln (2)^{-1}\right]\right)$.

Bivalves were quantified using a box core or suction sampling gear, both of which sample a large surface area and penetrate deep (40 to $60 \mathrm{~cm}$ ) into the sediment. This is essential for accurate estimation of densities of large bivalves that dwell deep (30 to $40 \mathrm{~cm}$ ) in the sediment and are sparsely distributed (Hines \& Comtois 1985). The box core sampled $0.0625 \mathrm{~m}^{2}$ of sediment area, whereas the suction apparatus sampled $0.170 \mathrm{~m}^{2}$. We therefore standardized densities in all samples to number of individuals $\mathrm{m}^{-2}$.

For the deep and mid-water sampling, we used a $25 \times 25 \mathrm{~cm}$ Gray O'Hara box core. Benthic cores were subsampled for sediment grain size and the remainder of the sediment was sieved on a $1 \mathrm{~mm}$ mesh screen. All bivalves retained on the screen were identified to the lowest possible taxonomic level (usually species), measured, and frozen for biomass estimates.

For the shallow-water sampling, we used a suction apparatus (with attached $1 \mathrm{~mm}$ mesh bag; Eggleston et al. 1992) and sampled within a cylinder of $0.17 \mathrm{~m}^{2}$ surface area to $\sim 40 \mathrm{~cm}$ depth. Bag contents were sieved on a $1 \mathrm{~mm}$ mesh screen. All bivalves retained on the screen were identified to species, measured, and frozen for biomass estimates. We compared average bivalve size between the deep and shallow strata for species that had sufficient numbers of individuals in both depth strata.

Gear comparison. Since 2 different gear types (box core and suction apparatus) were employed, a gear efficiency comparison was conducted. In the YR, at each of 3 sites that had high clam densities (high densities are preferred for gear comparisons; J. Hoenig pers. comm.) and that were accessible to both a large research vessel (using the box core) and a smaller vessel (using the suction apparatus), bivalves were sampled by 5 box cores and by 5 suction samples. We generated a mean density for core and suction samples for each site. These samples were compared with a 2-way mixed-model ANOVA with gear type as a fixed factor and site as a random factor.

Biomass estimates. To obtain ash free dry weight (AFDW in g), clams were dried to a constant weight $(\sim 48 \mathrm{~h})$ at $60^{\circ} \mathrm{C}$, and ashed at $550^{\circ} \mathrm{C}$ for $4 \mathrm{~h}$ to obtain ash weight. The largest and most abundant clams, Tagelus plebeius and Macoma balthica, were shucked prior to ashing to remove additional weight of the periostracum associated with large shells. The other clam species were too small for shucking $(<10 \mathrm{~mm}$ length) or had extremely thin shells and were ashed along with their shells. The effect of the periostracum on the AFDW of small clams was assumed to be negligible. 
Numerous Tagelus plebeius and Macoma balthica were collected (>200 ind. ranging from 8.5 to $35.2 \mathrm{~mm}$ shell length (SL) for $M$. balthica and 8.7 to $80.0 \mathrm{~mm}$ SL for T. plebeius). A regression of SL to AFDW was derived and used to estimate biomass from size for these 2 species. A sample of clams spanning the entire range of sizes ( 80 from each species) was chosen for the regression. Because large numbers of other species were not collected (<75 ind. per species), each clam was dried and ashed. For M. balthica and T. plebeius, our best-fit equations were the following power functions:

$$
\begin{gathered}
\text { Macoma balthica: AFDW }=0.000005057 \times \mathrm{SL}^{3.0068} ; \\
\left(\mathrm{r}^{2}=0.88, \mathrm{p}<0.001\right) \\
\text { Tagelus plebeius: AFDW }=0.000011 \times \mathrm{SL}^{2.6189} ; \\
\left(\mathrm{r}^{2}=0.94, \mathrm{p}<0.001\right)
\end{gathered}
$$

Shoreline sampling. Using GIS-based mapping of shorelines, in each river system we chose 6 to 8 replicate, independent subtidal sites in marsh creeks adjacent to (<5 m from shore) natural Spartina sp. marshes, 6 to 8 sites adjacent to bulkhead structures, and 5 to 7 sites adjacent to rip-rap shoreline structures. For each site, we tried to choose areas that had extensive lengths $(>50 \mathrm{~m})$ of the particular shoreline type. In the E-L River system, there were 6 replicate sites of each shoreline type, whereas in the YR, there were 5 to 7 sites of each type. At each site, we assessed water and habitat quality by measuring physical variables including water temperature, salinity, DO, turbidity, water depth, and sediment grain size (Table 2). Concurrently, we sampled benthos (bivalves only for the E-L, total infaunal community for the YR) and epibenthic predators to assess abundance and diversity.

Bivalve and predator sampling in the E-L River system: We used a suction apparatus (1 mm mesh bag) in a cylinder of $0.17 \mathrm{~m}^{2}$ area to $\sim 40 \mathrm{~cm}$ depth for the ben- thic samples, and a $2 \mathrm{~m}$ wide otter trawl net to sample along a $100 \mathrm{~m}$ transect bordering the marsh or altered shoreline for the predator samples. All bivalves and predators were identified to species; bivalves were measured to the nearest $0.1 \mathrm{~mm}$, whereas predators were measured to the nearest $\mathrm{mm}$. The abundance and diversity of benthic bivalves and predators was compared among the 3 shoreline types (natural marsh, rip-rap, and bulkhead) using fixed-factor ANOVA models with Tukey multiple comparison tests. For the predator analysis, we wanted to compare densities among unvegetated habitats, so we used sites without significant amounts of algae (which might have provided additional structure for predators and masked any differences among shoreline types).

Total infauna and predator sampling in the York River: We used a suction apparatus (1 $\mathrm{mm}$ mesh bag) in a cylinder of $0.17 \mathrm{~m}^{2}$ area to $\sim 40 \mathrm{~cm}$ depth for the benthic samples, and a $2 \mathrm{~m}$ wide otter trawl net to sample along a $100 \mathrm{~m}$ transect bordering the marsh or altered shoreline for the predator samples. Total infauna and predators were identified to the lowest possible taxonomic level (usually species). In addition, we analyzed a random subset of samples (2 to 3 per shoreline type) for estimates of abundance and Shannon-Wiener diversity $\left(H^{\prime}\right)$ of the entire infaunal benthic community (see Gray 2000). More samples were taken but were lost when our research building was demolished by Hurricane Isabel in 2003. An MDS (multi-dimensional scaling) analysis from a Bray-Curtis similarity matrix was performed on total infauna in the YR comparing communities by shoreline type using Primer v5.2.9 (Clark \& Gorley 2001, Clark $\&$ Warwick 2001). Infaunal community abundance and diversity and predator abundance and diversity were compared between natural marsh, rip-rap, and bulkhead habitats using fixed-factor ANOVA models, transforming data when necessary to homogenize variances.
Table 2. Mean $( \pm \mathrm{SE})$ values for temperature $\left(\right.$ Temp $\left.{ }^{\circ} \mathrm{C}\right)$, salinity $(\mathrm{psu}), \%$ sand, dissolved oxygen (DO in $\mathrm{mg} \mathrm{l}^{-1}$ ), and Secchi depth (in $\mathrm{cm}$ ) at natural marsh (NM), rip-rap (RR) and bulkhead (B) shorelines in the Elizabeth-Lafayette (E-L) River system and York River (YR). In last row for each system, ANOVA p-values are given for the comparison of the 3 shoreline types for each physical variable. There were no significant differences at $\alpha<0.05$

\begin{tabular}{|ccccccc|}
\hline & Site type & Temp & Salinity & \% sand & DO & Secchi \\
\hline E-L & NM & $22.8(0.2)$ & $17.6(1.2)$ & $42.4(14.8)$ & $6.0(1.0)$ & $75.5(10.4)$ \\
& RR & $23.5(0.7)$ & $19.1(1.3)$ & $44.3(18.4)$ & $7.8(1.3)$ & $80.3(13.0)$ \\
B & $23.2(0.8)$ & $16.9(0.9)$ & $60.7(14.9)$ & $9.2(1.2)$ & $71.3(14.3)$ \\
& $p$ & 0.770 & 0.410 & 0.878 & 0.220 & 0.882 \\
& & & & & & \\
YR & NM & $28.3(0.5)$ & $19.1(0.9)$ & $77.0(5.4)$ & & $45.1(6.1)$ \\
& RR & $28.0(0.4)$ & $19.3(0.8)$ & $82.9(5.2)$ & & $43.0(3.7)$ \\
& B & $29.3(0.5)$ & $18.0(2.0)$ & $63.4(16.3)$ & & 0.779 \\
& $p$ & 0.590 & 0.747 & 0.348 & & \\
\hline
\end{tabular}

\section{RESULTS}

\section{Deep versus shallow habitats}

Physical variables. In the deep stratum of the E-L River system, temperature was significantly lower (ANOVA unless otherwise indicated, $\mathrm{df}=1$ [source], 64[error], $F=83.12, \mathrm{p}<$ $0.0005)$ and salinity was significantly higher ( $\mathrm{df}=1,61, F=15.37$, $\mathrm{p}<0.0005$ ) than in the shallow stratum (Table 1). Much of the shallow stratum was within the relatively shallow Lafayette River, which receives considerable fresh-water runoff. DO was normoxic 
(> $2 \mathrm{mg} \mathrm{l}^{-1}$ ) ranging from 4.0 to $12.0 \mathrm{mg} \mathrm{l}^{-1}$ across all sampling sites and was significantly lower in deep than shallow waters (Table 1 ; df $=1,52, F=18.34, \mathrm{p}<$ 0.0005). In the YR, temperature on the cold sampling day was significantly higher at deep than shallow sites (df $=1,32, F=5.45, \mathrm{p}=0.026)$; salinity and DO did not differ significantly between depth strata (Table 1; salinity: $\mathrm{df}=1,31, F=2.61, \mathrm{p}=0.117$; DO: $\mathrm{df}=1,32, F$ $=0.27, \mathrm{p}=0.604$ ).

In the E-L River system, the mean percentage of sand was significantly lower (Table 1: df $=1,80, F=$ $7.55, \mathrm{p}=0.007$ ) and clay was significantly higher ( $\mathrm{df}=$ $1,80, F=4.52, \mathrm{p}=0.037$ ) in deep than in shallow sites. In the YR, the mean percentage of sand was lower and the percentage of clay higher in deep than in shallow sites, though these differences were marginally nonsignificant (Table 1; sand: $\mathrm{df}=1,28, F=3.45, \mathrm{p}=0.074$; clay: $\mathrm{df}=1,28, F=3.74, \mathrm{p}=0.063$ ). Hence, the deep sites were muddier than shallow sites in both river systems.

Bivalve collections. In the E-L River system 550 clams were collected in 120 samples. Common bivalve species included the thin-shelled Baltic macoma Macoma balthica, other thinshelled tellinids, $M$. mitchelli and M. tenta, the stout razor clam, Tagelus plebeius, the hard clam, Mercenaria mercenaria, as well as Mulinia lateralis, Aligena elevata, Anadara sp., Gemma gemma, and the angel wing clam $C y r-$ topleura costata (Table 3). The most numerous clams were $M$. balthica and T. plebeius, which comprised $40 \%$ and $36 \%$ of all clams, respectively.

In the YR, 43 clams of 8 species were collected in 32 samples, and included Macoma balthica, M. mitchelli, M. tenta, Tagelus plebeius, Aligena elevata, Anadara sp., and Cyrtopleura costata (Table 4). T. plebeius comprised $41 \%$ of all clams collected, while $M$. balthica comprised $32 \%$.

Gear comparison. There was no significant effect of gear type (i.e. box core or suction sampler) upon clam density (Fig. 2; 2-way ANOVA with Gear $\mathrm{p}=$ $0.511, \mathrm{df}=1$ and Site $\mathrm{p}=0.052, \mathrm{df}=2$ as factors, error $d f=2$ ). Hence, the 2 gears could be considered equivalent in sampling efficiency.

Bivalve density and diversity. In the E-L River system, bivalve density was significantly higher in the shallow stratum than in the deep stratum (Fig. 3a) (df $=1,119, F=55.52, p<0.0005)$. Bivalve density in the shallow stratum ( 75.7 bivalves $\mathrm{m}^{-2}$ ) was nearly 8 times higher than that of the deep stratum ( 9.5 bivalves $\mathrm{m}^{-2}$ ). Densities of bivalves in the deep sites within the confines of the Lafayette River (i.e. channel in the center of the Lafayette) were low and comparable to densities in the remainder of the deep sites. Species richness (i.e. number of bivalve species $\mathrm{m}^{-2}$ ) was significantly higher in the shallow stratum than in the deep stratum (Fig. 3b; df $=1,119, F=112.3$, p < 0.0005). Bivalve Shannon-Wiener diversity $\left(H^{\prime}\right)$, which includes both richness and evenness, was also significantly higher in shallow than in deep sites ( $\mathrm{df}=1,119$, $F=56.71, \mathrm{p}<0.0005)$.

In the YR, both density (Fig. 4a) and diversity (Fig. 4b) of bivalves were significantly higher in the shallow and mid strata compared to the deep stratum (log-transformed density: $\mathrm{df}=2,41, F=4.77, \mathrm{p}=0.014$, Tukey multiple comparison test; diversity $\mathrm{df}=2,29, F=$ 3.50, $\mathrm{p}=0.043$, Tukey test). The mid stratum did not

Table 3. Mean densities (ind. $\mathrm{m}^{-2}, \pm \mathrm{SE}$ ) of bivalves in 120 samples in the 2 sampling strata in the Elizabeth-Lafayette River system: deep (,$\geq 1.5 \mathrm{~m} \mathrm{MLW)} \mathrm{and}$ shallow ( $\mathrm{S},<1.5 \mathrm{~m}$ MLW). The p-value from ANOVA is in bold when significant. The difference column shows which stratum had higher densities when they differed significantly (Tukey test). $\mathrm{ns}=$ not significant $(\mathrm{p}>0.05)$

\begin{tabular}{|llccc|}
\hline Species & Deep & Shallow & $\mathrm{p}$ & Difference \\
\hline Macoma balthica & $0.6(0.4)$ & $32.7(7.4)$ & $\mathbf{0 . 0 0 0 5}$ & $\mathrm{S}>\mathrm{D}$ \\
Tagelus plebeius & $4.2(1.2)$ & $27.0(8.2)$ & $\mathbf{0 . 0 0 0 5}$ & $\mathrm{S}>\mathrm{D}$ \\
Macoma mitchelli & $0.2(0.2)$ & $2.3(0.8)$ & $\mathbf{0 . 0 0 2}$ & $\mathrm{S}>\mathrm{D}$ \\
Aligena elevata & $2.6(1.9)$ & $9.2(3.9)$ & 0.090 & $\mathrm{~ns}$ \\
Mercenaria mercenaria & $0.4(0.3)$ & $2.1(1.0)$ & $\mathbf{0 . 0 2 8}$ & $\mathrm{S}>\mathrm{D}$ \\
Mulinia lateralis & 0 & $1.0(0.5)$ & $\mathbf{0 . 0 1 1}$ & $\mathrm{S}>\mathrm{D}$ \\
Anadara sp. & 0 & $0.3(0.3)$ & 0.150 & $\mathrm{~ns}$ \\
Cyrtopleura costata & $0.4(0.4)$ & 0 & 0.490 & $\mathrm{~ns}$ \\
Macoma tenta & $1.0(0.4)$ & 0 & 0.115 & $\mathrm{~ns}$ \\
Gemma gemma & $0.2(0.2)$ & $1.1(0.8)$ & 0.172 & $\mathrm{~ns}$ \\
Mya arenaria & 0 & $0.2(0.2)$ & 0.150 & $\mathrm{~ns}$ \\
Total bivalves & $9.5(2.6)$ & $75.7(11.7)$ & $\mathbf{0 . 0 0 0 5}$ & $\mathrm{S}>\mathrm{D}$ \\
\hline
\end{tabular}

Table 4. Mean densities (ind. $\mathrm{m}^{-2}, \pm \mathrm{SE}$ ) of bivalves in 32 samples in the 2 sampling strata in the York River: deep (,$\geq 3.0 \mathrm{~m} \mathrm{MLW})$, and shallow $(\mathrm{S},<3.0 \mathrm{~m}$ $\mathrm{MLW})$. The $\mathrm{p}$-value from the ANOVA is listed (significant values in bold). The difference column shows which stratum had higher densities when they differed significantly (Tukey test). $\mathrm{ns}=$ not significant $(\mathrm{p}>0.1) .{ }^{*}=\log$-transformed data used for ANOVA because of heterogeneity of variance

\begin{tabular}{|llccc|}
\hline Species & Deep & Shallow & $\mathrm{p}$ & Difference \\
\hline Macoma balthica & 0 & $10.9(4.5)$ & $\mathbf{0 . 0 7 4}^{*}$ & $\mathrm{~S}>\mathrm{D}$ \\
Tagelus plebeius & $1.6(1.6)$ & $12.4(6.7)$ & 0.297 & $\mathrm{~ns}$ \\
Macoma mitchelli & 0 & $2.9(1.7)$ & 0.264 & $\mathrm{~ns}$ \\
Aligena elevata & 0 & $1.5(1.5)$ & 0.509 & $\mathrm{~ns}$ \\
Anadara sp. & $1.6(1.6)$ & 0 & 0.141 & $\mathrm{~ns}$ \\
Cyrtopleura costata & 0 & $2.9(1.7)$ & 0.264 & $\mathrm{~ns}$ \\
Macoma tenta & 0 & $0.7(0.7)$ & 0.509 & $\mathrm{~ns}$ \\
Total bivalves & $3.2(2.1)$ & $30.7(8.2)$ & $\mathbf{0 . 0 2 3}^{*}$ & $\mathrm{~S}>\mathrm{D}$ \\
\hline
\end{tabular}




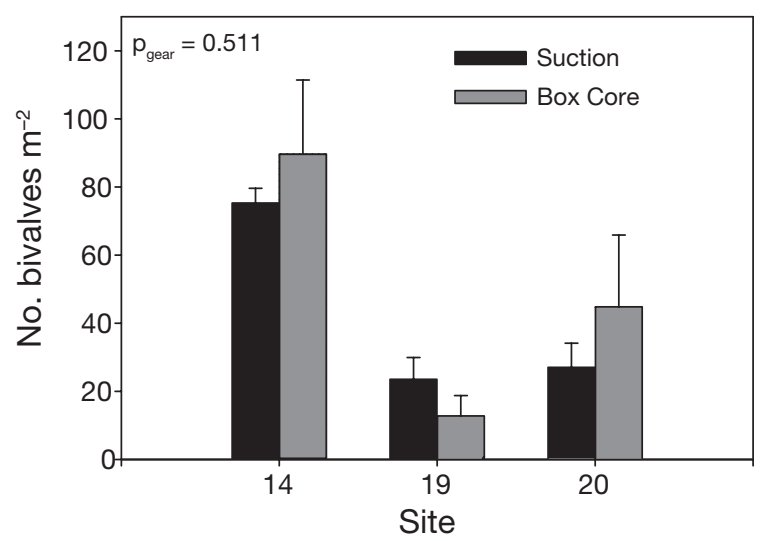

Fig. 2. Mean (+SE) density of bivalves by site with 2 different sampling gears. Samples were taken from 3 sites $(14,19$ and 20) in the upriver region of the York River with $n=5$ at each site

a) Mean bivalve density

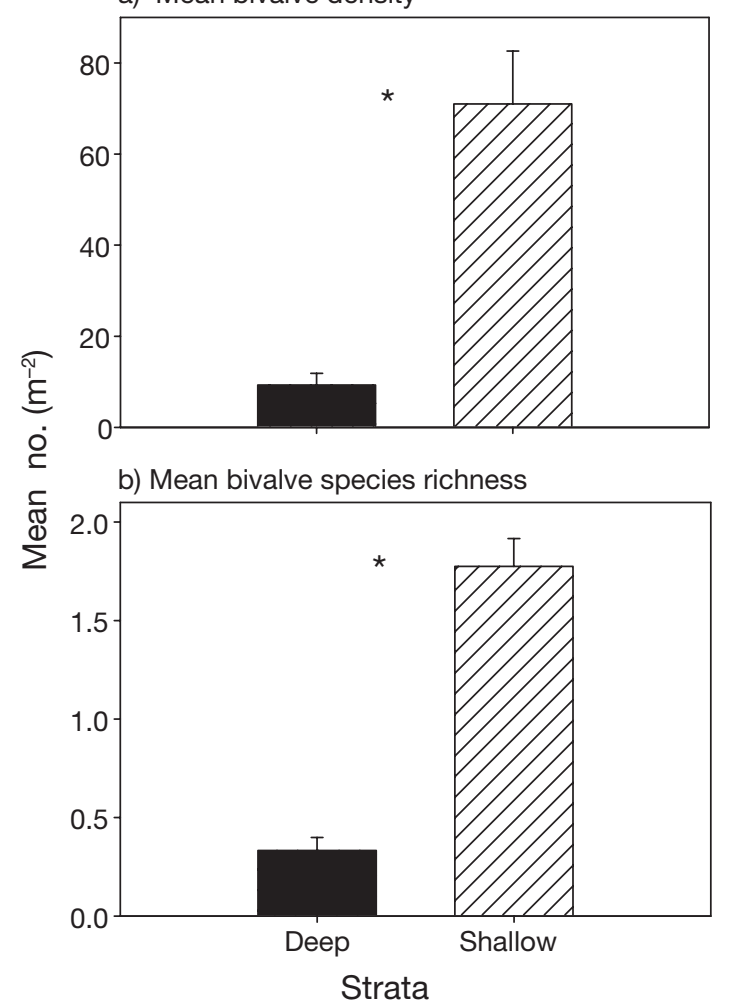

Fig. 3. Mean (+SE) bivalve (a) density and (b) species richness for 2 depth strata in the Elizabeth-Lafayette River system: deep and shallow. Asterisk indicates significant differences (ANOVA $\mathrm{p}<0.05$ )

differ significantly from the shallow stratum; thus, for subsequent analyses, we treated the mid and shallow strata as a single shallow category.

Abundance and area. As an estimate of the overall abundance of bivalves in the 2 depth strata, we quantified the area available for sampling in each stratum

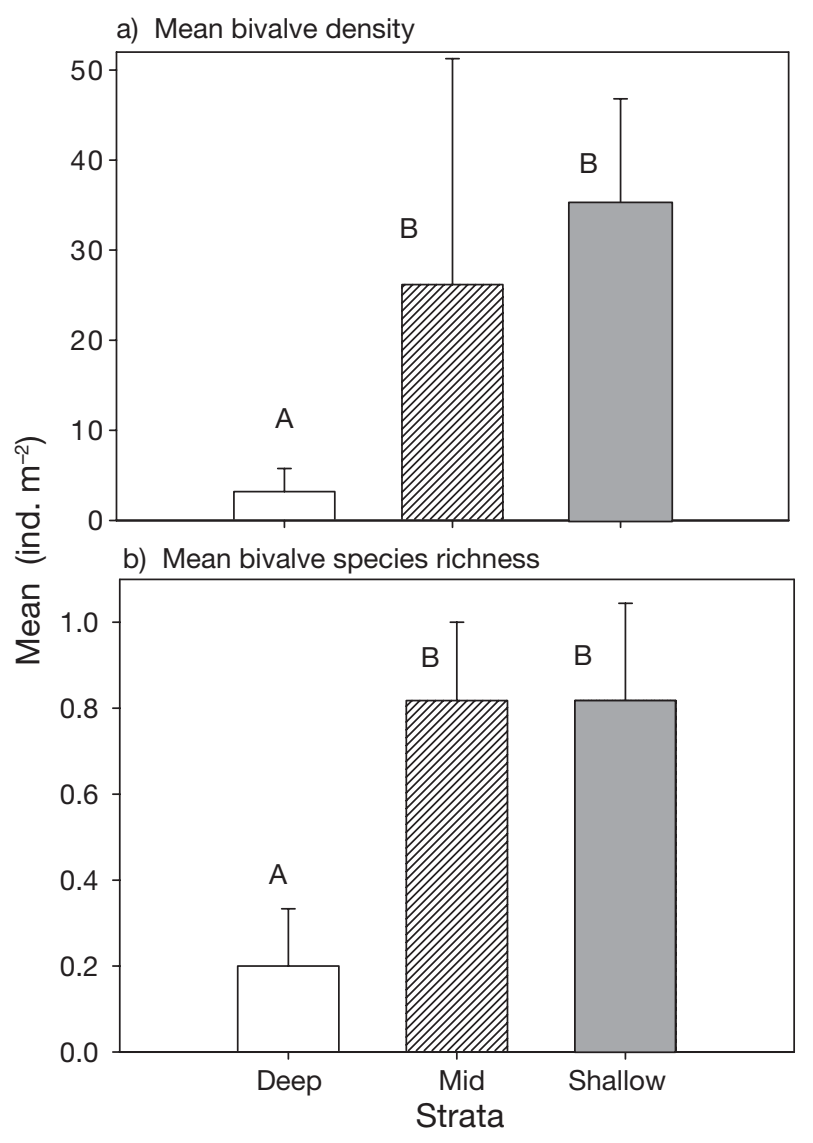

Fig. 4. Mean (+SE) bivalve (a) density and (b) species richness for 3 depth strata: deep ( $\geq 3.0 \mathrm{~m})$, mid (1.5 to $2.9 \mathrm{~m}$ ) and shallow $(<1.5 \mathrm{~m})$ water in the York River. Different capital letters above bars indicate significant differences in logtransformed data (Tukey test)

and multiplied by bivalve density. In the E-L River system, we estimated 468 ha in the shallow stratum and 879 ha in the deep stratum (Fig. 5a). The percentage of the total area within the shallow stratum (35\%) was nearly half that in the deep stratum (65\%). Multiplying the area available for sampling by the mean density of bivalves, we estimated abundances of 354.4 million for the shallow stratum ( $79 \%$ of total) and 91.3 million for the deep stratum (21\% of total) (Fig. 5b). In the YR (including creeks and coves), the shallow area of the river ( $<2 \mathrm{~m}$ as defined by topographic contours) was 8145 ha $(33 \%$ of total area), whereas the deep area was 16872 ha (67\% of total area; Fig. 5c). Multiplying by density, abundance was estimated at 2750 million bivalves in the shallow stratum ( $80 \%$ of total) and 625 million bivalves in the deep stratum $(20 \%$ of total; Fig. 5d).

Sediment and clam regressions. In the E-L River system, bivalve density in both depth strata was positively associated with percent sand (Fig. 6a; non-linear regression $\mathrm{p}<0.0005, \mathrm{r}^{2}=31.6 \%$ ) and negatively associ- 

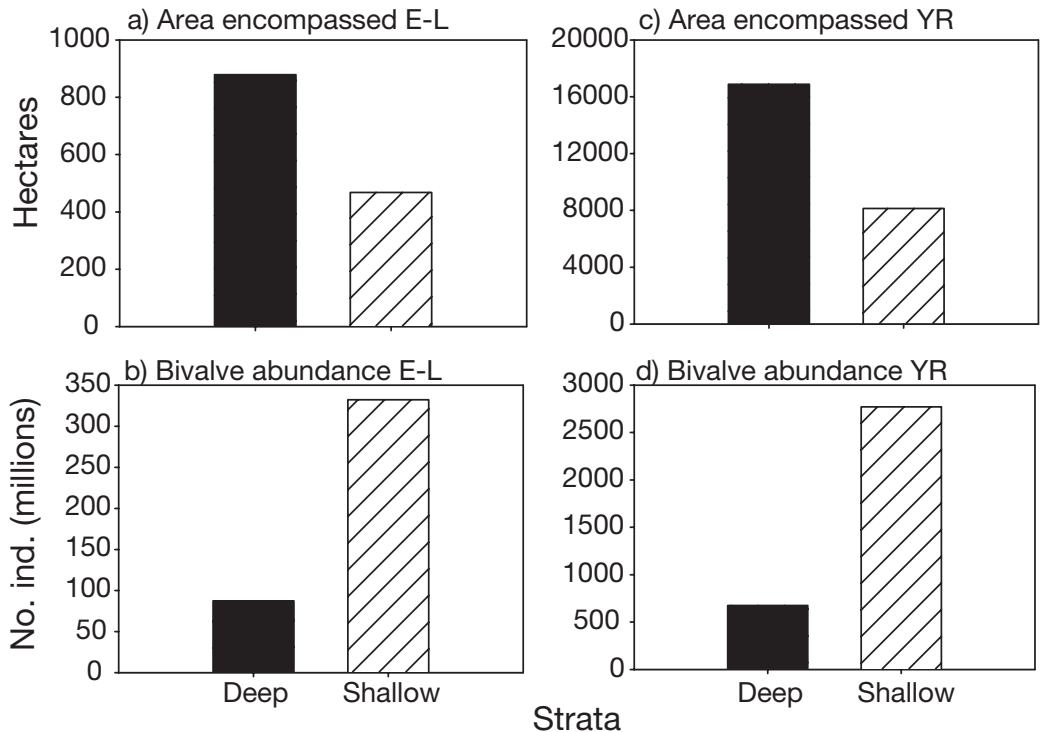

Fig. 5. (a) Area encompassed by sampling strata within the Elizabeth-Lafayette (E-L) River system. (b) Estimated abundance of bivalves in sampling strata within the E-L River system. (c) Area encompassed by sampling strata within the York River (YR). (d) Estimated abundance of bivalves in sampling strata within YR

a) \% Sand vs. Clam density

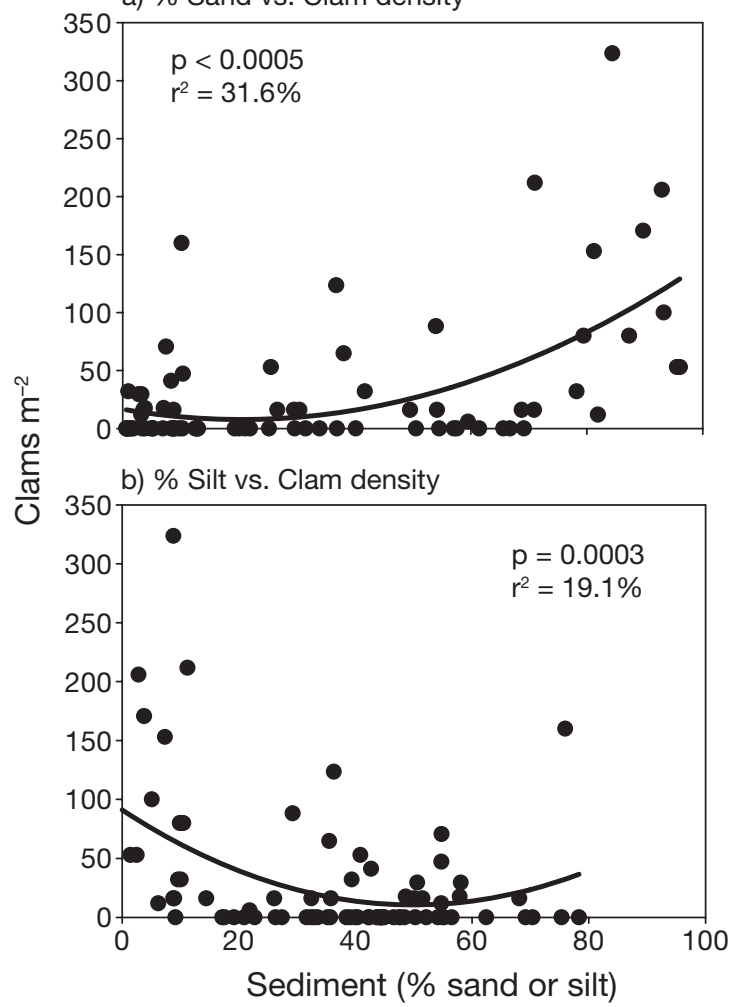

Fig. 6. Non-linear regressions in the Elizabeth-Lafayette River system of (a) clam density (ind. $\mathrm{m}^{-2}$ ) vs. percent sand in surface sediments from both sampling strata, and (b) clam density vs. percent silt in surface sediments from both sampling strata ated with percent silt (Fig. 6b; non-linear regression $p=0.0003, r^{2}=19.1 \%$ ) of surface sediments. In the YR, with fewer samples and fewer clams collected, there were no significant relationships between bivalve density and sediment type (clams vs. \% sand regression $\mathrm{p}=$ 0.648 , clams vs. $\%$ silt $\mathrm{p}=0.653$ ).

Bivalve size and biomass comparisons. In the E-L River system, bivalves were significantly larger in the shallow than in the deep stratum (Fig. 7a; df = $1,545, F=8.17, p=0.004)$. Specifically, Tagelus plebeius, one of the most abundant bivalves, was significantly larger in the shallow stratum compared to the deep stratum (Fig. 7b; df $=1,197, F=$ 6.54, $\mathrm{p}=0.011$ ). Similarly, in the YR, bivalves were much larger in shallow than in deep habitats, though this difference was not significant (Fig. $7 \mathrm{C}$; df $=$ 1,41, $F=0.47, \mathrm{p}=0.498$ ).

As with density, we standardized biomass in all samples to $\mathrm{g}$ AFDW $\mathrm{m}^{-2}$. The pattern for bivalve biomass between the 2 strata in both river systems was equivalent to that for density. In the E-L River system, mean bivalve biomass $\mathrm{m}^{-2}$ was significantly higher in the shallow stratum (about 13 times higher) than in the deep stratum (Fig. 8a; df =1,118, F= $27.7, \mathrm{p}<0.0005)$. The total biomass of all bivalve samples was $47.997 \mathrm{~g}$ AFDW. Of the total, Tagelus plebeius comprised $73.1 \%$, Macoma balthica comprised $25.2 \%$, and together these 2 most common species accounted for $98.3 \%$ of the bivalve biomass. T. plebeius biomass was significantly higher in the shallow stratum $(4.95+1.69 \mathrm{~g}$ AFDW $\left.\mathrm{m}^{-2}\right)$ compared to the deep stratum $(0.45+0.26 \mathrm{~g}$ AFDW m $\left.{ }^{-2}\right)(\mathrm{df}=1,118, F=13.47, \mathrm{p}=0.002)$, due to the much larger size of these clams in the shallow stratum (Fig. 7b). M. balthica was the most numerous bivalve and the second most important in terms of biomass; $M$. balthica biomass was significantly higher in the shallow stratum $\left(1.97 \pm 0.505 \mathrm{~g} \mathrm{AFDW} \mathrm{m}^{-2}\right)$ than in the deep stratum $\left(0.039 \pm 0.038 \mathrm{~g} \mathrm{AFDW} \mathrm{m}^{-2}\right)(\mathrm{df}=1,118, F=29.76, \mathrm{p}<$ 0.0005). Similarly, in the YR, mean bivalve biomass was significantly higher in shallow than in deep habitats (Fig. 8b: $\mathrm{df}=1,30, F=8.04, \mathrm{p}=0.008$ ).

Biomass percentages. To generate an estimate of total bivalve biomass in each of the depth strata, we calculated the product of the area and the mean biomass per unit area of each stratum. In the E-L River system, there were 468 ha in the shallow stratum and 879 ha in the deep stratum (Fig. 5a); total bivalve biomass was approximately 7 times higher in the shallow than in the deep stratum (Fig. 8c). Total biomass in the system was $36334 \mathrm{~kg}$ AFDW, of which 87.6\% was 
a) All bivalves, E-L

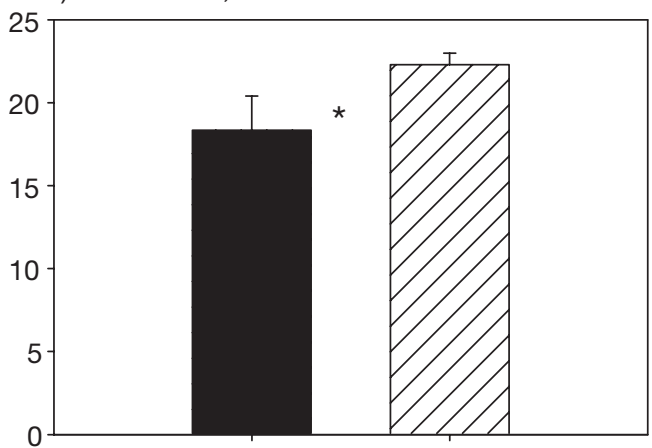

b) Tagelus plebeius, E-L

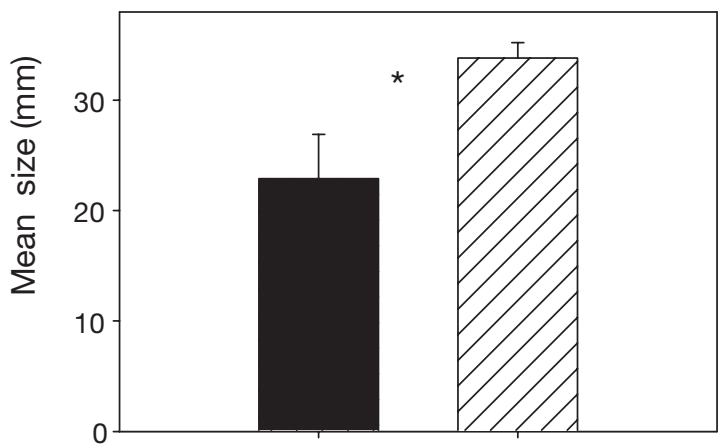

c) All bivalves, $\mathrm{YR}$

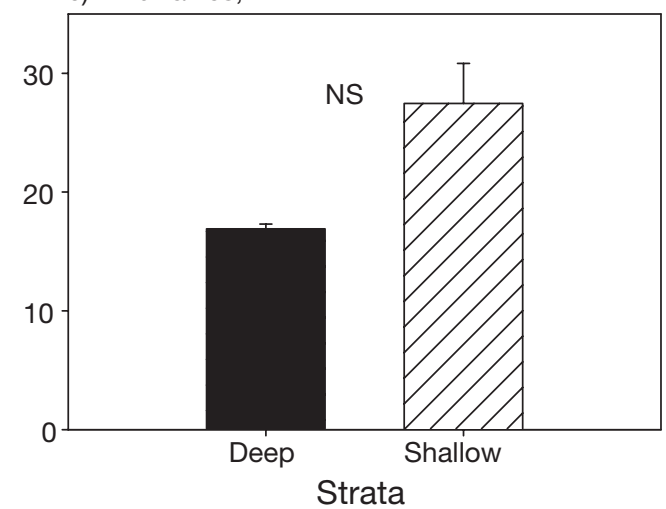

Fig. 7. (a) Mean size (error bars + SE) of all bivalves in deep and shallow strata in the Elizabeth-Lafayette (E-L) River system. (b) Mean size of Tagelus plebeius in deep and shallow strata in the E-L system. (c) Mean size of all bivalves in deep and shallow strata in the York River (YR). Asterisks between bars indicate significant differences $(p<0.05)$. NS: not significant

within the shallow stratum and $12.4 \%$ was within the deep stratum. The low biomass in the deep stratum occurred because this stratum had few bivalves, and those that were present were small. Similarly, in the YR, there were 8145 ha in the shallow stratum and 16873 ha in the deep stratum (Fig. 5c), but biomass per unit area was much higher in the shallow stratum, resulting in 12 times higher total biomass for the shallow than for the deep stratum (Fig. 8d).

\section{Shoreline comparisons}

Physical variables. There were no significant differences in physical variables (temperature, salinity, Secchi depth, sediment type) by shoreline type, either in the E-L River system or the YR (Table 2); however in the E-L River system, biological parameters were associated with some of the physical ones. In the E-L River system, among the shallow habitats, total clam density was positively associated with percent sand $\left(p=0.003, r^{2}=0.32\right)$ and negatively associated with percent silt $(\mathrm{p}=0.004$, $\mathrm{r}^{2}=0.30$ ). In contrast, in the YR shallow habitats, we found no significant relationships between bivalve density and sediment type (clam vs. percent sand regression $p=0.648$, clams vs. percent silt $p=0.653$ ), possibly due to the lower numbers of clams collected in the YR.

Shoreline bivalve and infauna densities. In the E-L River system, Macoma balthica density differed significantly among shoreline types (Fig. 9a; ANOVA on logtransformed data: $\mathrm{df}=2,15, F=4.12, \mathrm{p}=0.037$ ); the highest densities occurred adjacent to natural marsh. For Tagelus plebeius there was no significant difference in density among shoreline types (Fig. 9b; ANOVA on log-transformed data: $\mathrm{df}=2,15, F=0.63$, $\mathrm{p}=0.547$ ). Total bivalve densities followed the patterns for $M$. balthica with slightly higher densities adjacent to natural marsh (109.8 bivalves $\mathrm{m}^{-2}$ ) than rip-rap (38.2 bivalves $\mathrm{m}^{-2}$ ) or bulkhead (78.4 bivalves $\mathrm{m}^{-2}$ ) ( $\mathrm{df}=2,15, F=2.12, \mathrm{p}=0.155$ ). In the $\mathrm{YR}$, total bivalve densities were moderate adjacent to natural marsh $\left(24.4 \mathrm{~m}^{-2}\right)$ and rip-rap $\left(31.2 \mathrm{~m}^{-2}\right)$ and low adjacent to bulkhead (18.2 $\mathrm{m}^{-2}$ ) (ANOVA on log-transformed densities; $d f=2,27, F=1.77, p=0.190)$. There were slightly higher densities of M. balthica and T. plebeius adjacent to rip-rap and natural marsh compared to bulkhead shorelines, however these differences were not significant $(M$. balthica $\mathrm{p}=0.987, T$. plebeius $\mathrm{p}=$ 0.377 ) since relatively low numbers of both species were collected and variability was high.

In the YR, 26 species of macrofauna were found, including several species of polychaetes and amphipods, along with bivalves (Table 5). Shannon-Wiener diversity of all infauna (including bivalves, polychaetes, amphipods, etc.), which integrates species richness and evenness of the infaunal community, was significantly greater adjacent to both natural marsh and rip-rap compared to bulkhead in the YR (Fig. 10a; $\mathrm{df}=2,4, F=14.4$, $\mathrm{p}=0.015$; Tukey test). The density of organisms in the total benthic community followed a similar pattern, with significantly greater values for natural marsh and rip-rap compared to bulkhead habitats (Fig. 10b; df =2,4,F= 11.63, $\mathrm{p}=0.022$; Tukey test). In addition, multidimensional scaling (MDS) of the macrobenthic community showed a clear separation between bulkhead sites and natural marsh or rip-rap sites in the YR (Fig. 11) with 
a) Mean biomass E-L

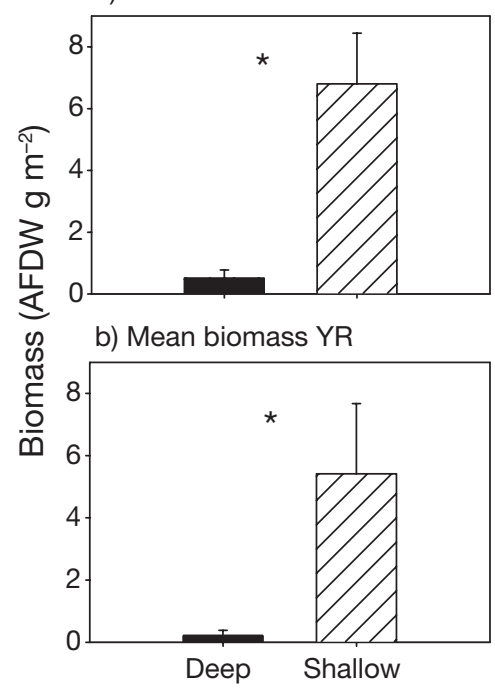

c) Total biomass E-L

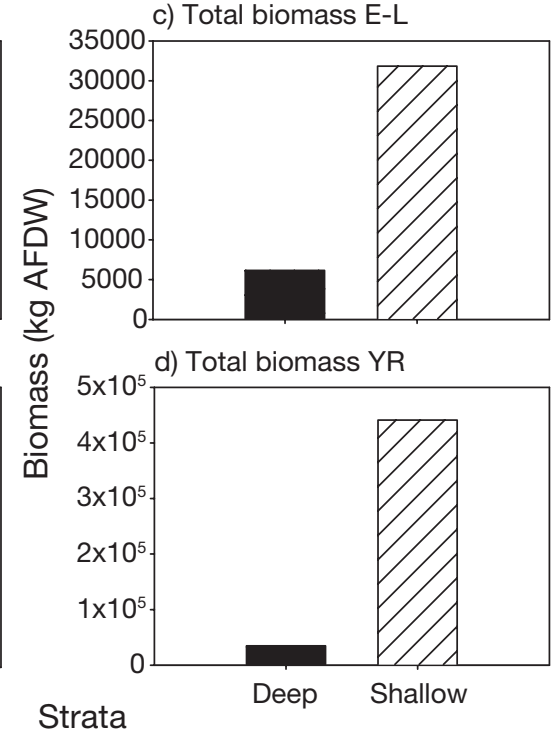

Fig. 8. Mean (+SE) bivalve biomass $\mathrm{m}^{-2}$ in deep and shallow strata for (a) Elizabeth-Lafayette (E-L) River system and (b) York River (YR). Total biomass (kg AFDW) of bivalves in deep and shallow strata for (c) E-L system and (d) York River. Asterisks between bars indicate significant differences (ANOVA, $\mathrm{p}<0.05$ )

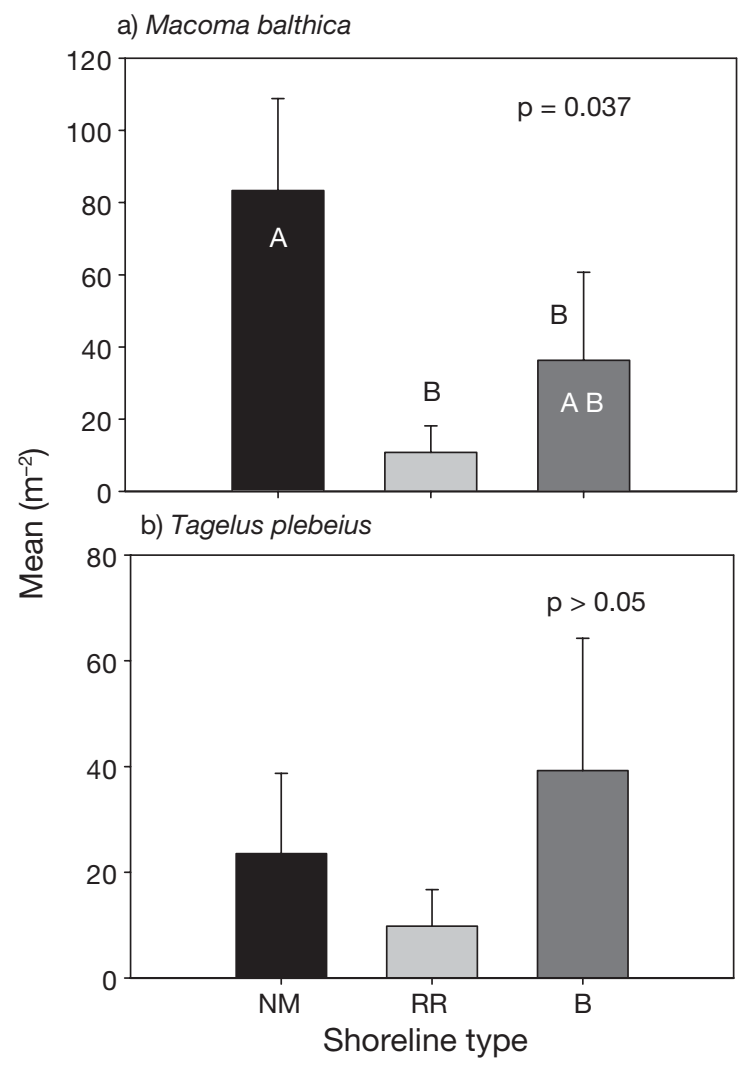

Fig. 9. Macoma balthica and Tagelus plebeius. Mean (+SE) density of clams in shallow subtidal habitats adjacent to natural marsh (NM), rip-rap (RR) or bulkhead (B) shorelines in the Elizabeth-Lafayette River system for the bivalves (a) M. balthica and (b) T. plebeius. Different capital letters above or within bars indicate significant differences (Tukey test) stress $=0.01 ;$ ANOSIM, global $\mathrm{R}=0.575$ and $\mathrm{p}=0.048$, indicating that there were significant differences among groups although some groups were overlapping.

Shoreline predators. In the E-L River system, fish abundance did not change appreciably with shoreline type (Fig. 12a; $\mathrm{df}=2,10, F=0.03, \mathrm{p}=0.973$ ). There was, however, a tendency toward higher blue crab abundance adjacent to natural marsh than in rip-rap or bulkhead shorelines (Fig. 12b), though variability was high and this difference was not significant $(\mathrm{df}=2,10, F=1.14, \mathrm{p}=$ 0.359). In the YR, a pattern tending towards slightly higher abundance of predators in natural marsh compared to rip-rap or bulkhead shorelines occurred both in fish (Fig. 12a) and in total crabs, including spider crabs and mud crabs (Fig. 12b), though these differences were not significant (Fish: df $=2,45, F=0.53$, $\mathrm{p}=0.592, \mathrm{crab}: \mathrm{df}=245, F=0.47, \mathrm{p}=$ 0.628). Notably, including data from both rivers, there were significantly higher crab densities in natural marsh than in rip-rap or bulkhead shorelines (2-way ANOVA with River and Shoreline as factors; Shoreline $\mathrm{df}=2,55$, $F=3.63, \mathrm{p}=0.033$, Tukey test). With fish predator data from both rivers, there were no significant differences in densities among levels of the factors Shoreline type or River (2-way ANOVA; Shoreline df $=2,55, F=0.13, \mathrm{p}=$ 0.876).

The diversity of both total predators (Fig. 13a) and fish predators (Fig. 13b) in the E-L River system was higher in natural marsh than in rip-rap or bulkhead habitats, and these differences were marginally significant (total predators $\mathrm{p}=0.089$, fish predators $\mathrm{p}=$ 0.123). A similar tendency was seen in YR total predator richness (Fig. 13c) and fish predator richness (Fig. 13d), though variability was high and the patterns were non-significant (total predators $\mathrm{p}=0.795$, fish predators $\mathrm{p}=0.765$ ).

\section{DISCUSSION}

\section{Bivalve abundance and diversity in deep and shallow habitats}

Shallow-water habitats $(<1.5 \mathrm{~m})$ in both the E-L River system and YR in Chesapeake Bay had significantly higher bivalve density and abundance than did adjacent deep-water habitats. Specifically, bivalve density in shallow habitats was over 7 times higher than that in deep habitats of the E-L River system and 
Table 5. Mean number of macrofaunal organisms per $0.17 \mathrm{~m}^{2}$ sample by shoreline type collected in suction samples ( $1 \mathrm{~mm}$ sieve) in the York River with taxon indicated $(\mathrm{A}=$ amphipod, $\mathrm{B}=$ bivalve, $\mathrm{G}=$ gastropod, $\mathrm{O}=$ other, $\mathrm{P}=$ polychaete, $\mathrm{S}=$ shrimp). Species are listed in order of most abundant to least abundant across all 3 shoreline types

\begin{tabular}{|lccc|}
\hline Species & Bulkhead & Rip-rap & Natural marsh \\
\hline Aligena elevata (B) & 0.0 & 5.7 & 17.5 \\
Tagelus plebeius (B) & 5.0 & 6.7 & 5.5 \\
Phoronis sp. (O) & 0.0 & 5.0 & 8.0 \\
Notomastus sp. (P) & 1.0 & 7.0 & 4.5 \\
Spiochaetopterus sp. (P) & 0.0 & 11.7 & 0.5 \\
Geukensia demissa (B) & 0.0 & 0.0 & 7.5 \\
Littoraria littorea (G) & 0.0 & 1.3 & 2.0 \\
Glycera americana (P) & 0.5 & 0.7 & 2.0 \\
Macoma balthica (B) & 0.5 & 0.7 & 1.0 \\
Mercenaria mercenaria (B) & 0.0 & 0.0 & 2.0 \\
Loimia medusa (P) & 0.0 & 0.3 & 1.5 \\
Macoma mitchelli (B) & 1.5 & 0.0 & 0.0 \\
Ensis directus (B) & 0.0 & 0.0 & 1.5 \\
Neanthes (Nereis) succinea (P) & 0.0 & 1.0 & 0.5 \\
Capitella capitata (P) & 0.0 & 1.3 & 0.0 \\
Diopatra cuprea (P) & 0.0 & 0.7 & 0.5 \\
Drilonereis longa (P) & 0.0 & 0.7 & 0.5 \\
Scoloplos fragilis (P) & 1.0 & 0.0 & 0.0 \\
Scolelepis squamata (P) & 0.0 & 0.0 & 1.0 \\
Mysidopsis bigelowii (S) & 0.0 & 0.3 & 0.5 \\
Pectineria gouldii (P) & 0.0 & 0.3 & 0.5 \\
Spionidae (P) & 0.5 & 0.3 & 0.0 \\
Upogebia sp. (S) & 0.0 & 0.0 & 0.5 \\
Mulinia lateralis (B) & 0.0 & 0.3 & 0.0 \\
Rhyncecoela anopla (O) & 0.0 & 0.3 & 0.0 \\
Gammarid amphipod (A) & 0.0 & 0.3 & 0.0 \\
Mean number of organisms & 10.0 & 44.7 & 50.5 \\
Mean number of species & 4.5 & 11.0 & 13.0 \\
\hline
\end{tabular}

bivalves in the system resided in the shallow stratum. Similarly, in the YR, $80 \%$ of the total estimated bivalves resided in shallow habitats. This suggests that the shallows are extremely important for estuarine food webs, and these habitats have typically not been sampled adequately.

As with abundance, bivalve biomass was significantly higher in shallow benthic habitats than in deep habitats in both study systems. Since bivalve density in shallow-water habitats was nearly 7 -fold higher than that in the deep habitats, and since bivalves were larger in the shallows, the resultant biomass was much greater in shallow habitats. Within the E-L River system, of the estimated total bivalve biomass, $84 \%$ was in shallow habitats. In the YR, approximately $93 \%$ of the total estimated biomass was in the shallow stratum.

The clams that comprised the biomass in the shallow stratum were typically large individuals of the Baltic macoma Macoma balthica, and the stout razor clam Tagelus plebeius. Although some $T$. plebeius and hard clams, Mercenaria mercenaria, appeared in deep habitats, they were usu-

was similarly 7 times higher in shallow compared to deep habitats in the YR. Bivalve diversity (richness and Shannon-Wiener $H^{\prime}$ ) and density of all 11 bivalve species but 1 (Anadara sp.) were higher in shallow than in deep habitats of E-L. In the YR, bivalve diversity was approximately 4 times greater in shallow than deep habitats.

Although high densities of bivalves have been observed previously in Chesapeake Bay (Hawthorne \& Dauer 1983, Tourtellotte \& Dauer 1983, Holland 1985, Dauer \& Alden 1995, Seitz et al. 2001) and densities can be strikingly high during spring recruitment, no study to date has demonstrated such relatively high densities in shallow compared to deep habitats. These relatively high bivalve densities persist even in the face of intense predation (Virnstein 1977), as many of the common species possess evolutionary adaptations, such as the ability to bury deep (Hines \& Comtois 1985) to avoid predation (Seitz et al. 2001).

Even when accounting for the larger area of deepwater habitats, total bivalve abundance was much higher in shallow habitats due to the elevated densities of bivalves in the shallows. Within the E-L River system, we estimated that approximately $79 \%$ of the ally smaller individuals (juveniles) with low biomass. Most of the large $M$. balthica in the shallow habitats were reproductively active, since they mature at shell lengths greater than about $15 \mathrm{~mm}$ (Delano 2004). Moreover, $M$. balthica in Chesapeake Bay do not undergo ontogenetic changes in habitat (Seitz et al. 2003b), which is common in the Baltic (Beukema 1993). Consequently, most of the spawning stock of $M$. balthica resides in shallow habitats. $M$. balthica, $T$. plebeius, and Mercenaria mercenaria are considered 'estuarine endemics' (sensu Boesch 1977) and are thought to be the mainstay of the benthic community, persisting through environmental fluctuations, unlike 'opportunistic' counterparts such as short-lived polychaetes. Moreover, many of the bivalves are extremely tolerant of temperature fluctuations, and M. balthica can withstand up to 3 wk of low dissolved oxygen (Seitz et al. 2003a).

In large estuaries (e.g. Chesapeake Bay), bivalves make up a high percentage of benthic prey biomass (Dauer et al. 1987, Hagy 2002), yet long-term monitoring programs have not regularly sampled shallow areas <1 m MLW (Weisberg et al. 1997, D. Dauer pers. comm.). For instance, in Chesapeake Bay prior to 1996, 
a) Shannon-Wiener diversity

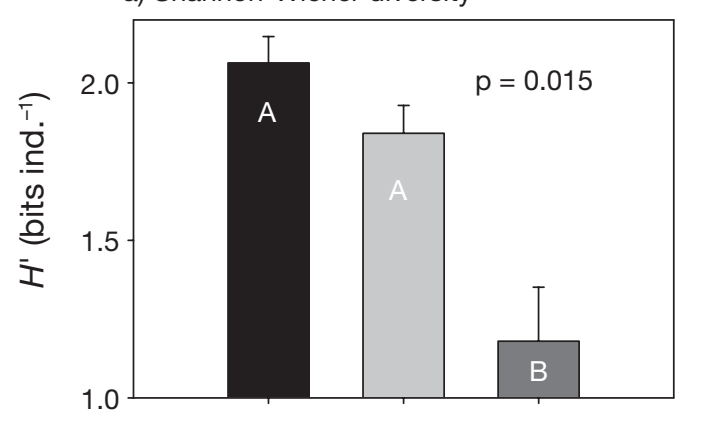

b) Number of infaunal organisms

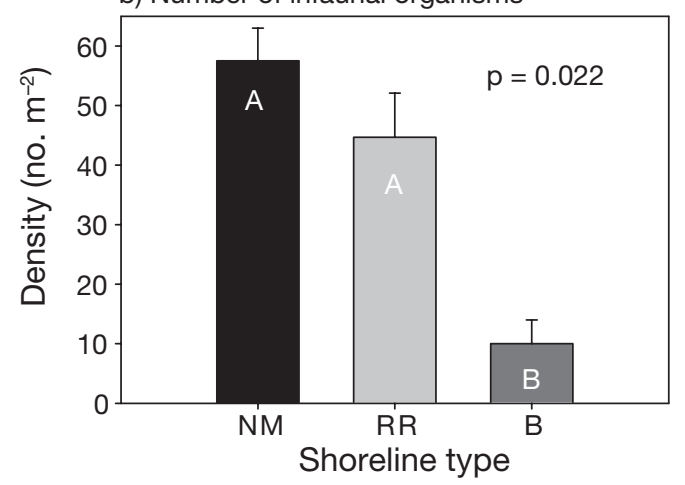

Fig. 10. (a) Mean (+SE) Shannon-Wiener diversity and (b) number of organisms of all benthic infauna in a subset (2 to 3 per habitat) of shallow subtidal sites adjacent to natural marsh (NM), rip-rap (RR) or bulkhead (B) shorelines in the York River. Different capital letters within bars indicate significant differences (Tukey test)

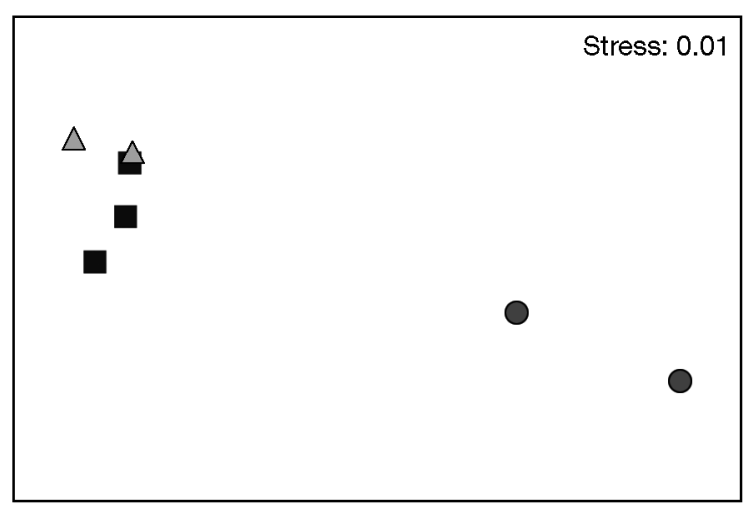

Bulkhead

Rip rap $\triangle$ Natural marsh

Fig. 11. Multidimensional scaling plot of York River community macrofauna adjacent to the 3 shoreline types: natural marsh, rip-rap, and bulkhead). Global $\mathrm{R}=0.575, \mathrm{p}=0.048$ and stress are from ANOSIM analysis for differences among shoreline types

shallow areas were not sampled at all, and currently the Chesapeake Bay benthic monitoring program's random sampling regime only samples a few shallow areas, but only those deeper than $1.0 \mathrm{~m}$ MLW (in proportion to their occurrence). In addition, the sampling

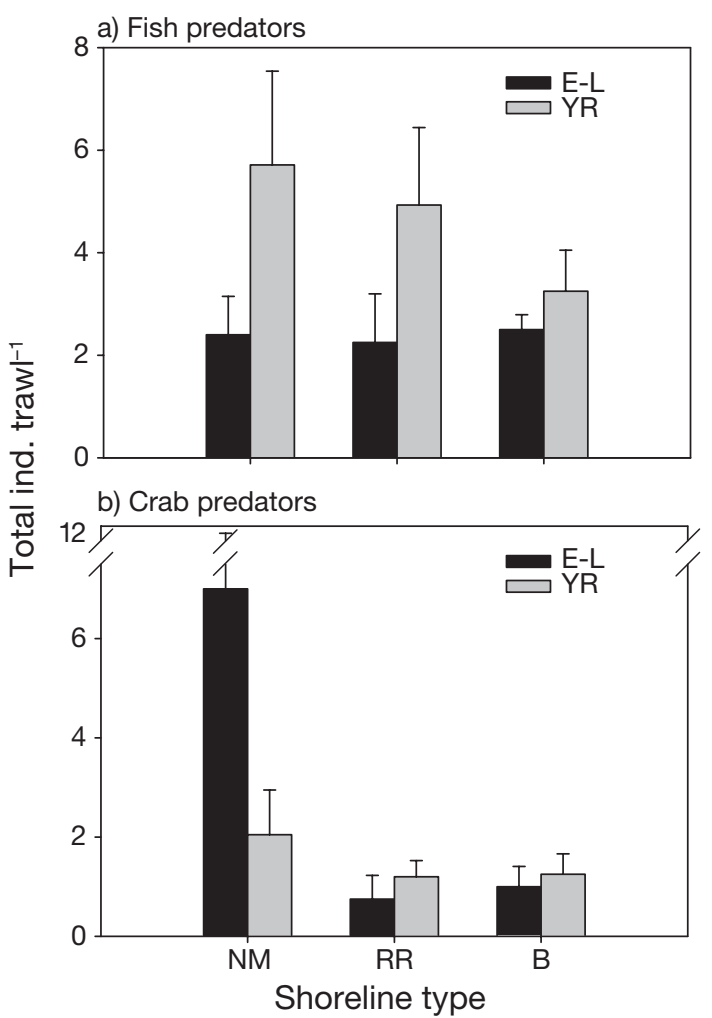

Fig. 12. Mean (+SE) density of predators per $20 \mathrm{~m}^{2}$ area trawled in shallow subtidal habitats adjacent to natural marsh (NM), rip-rap (RR) or bulkhead (B) shorelines in the Elizabeth-Lafayette (E-L) River system (E-L only included habitats without significant algal structure) and York River (YR).

(a) Fish and (b) Callinectes sapidus, the blue crab

program uses a 'Young grab' that penetrates $10 \mathrm{~cm}$ into the sediment. This shallow penetration depth could potentially miss deep-dwelling species, such as Macoma balthica, which have populations with over $50 \%$ of their biomass below $10 \mathrm{~cm}$ in some habitats (Hines \& Comtois 1985, Dauer et al. 1987). Thus, a significant and substantial segment of benthic prey biomass in estuaries such as Chesapeake Bay may have been overlooked in mechanistic interpretations or modeling of critical ecological processes, such as energy transfer in food webs. Because of the substantial fraction of biomass in the shallows demonstrated in our study, there is a clear need for additional modeling efforts that incorporate these important habitats. We have undertaken initial modeling studies of the YR that will add the important shallow-water benthic biomass to existing food-web models to estimate the impacts of this additional prey resource to upper trophic levels (Seitz et al. unpubl. data).

Shallow habitats are likely to be much more significant than formerly believed as feeding grounds for epibenthic predators such as the blue crab and demersal fish (e.g. Atlantic croaker Micropogonias un- 
a) E-L predator richness

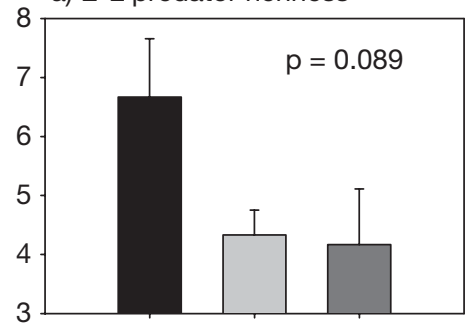

b) E-L fish species richness

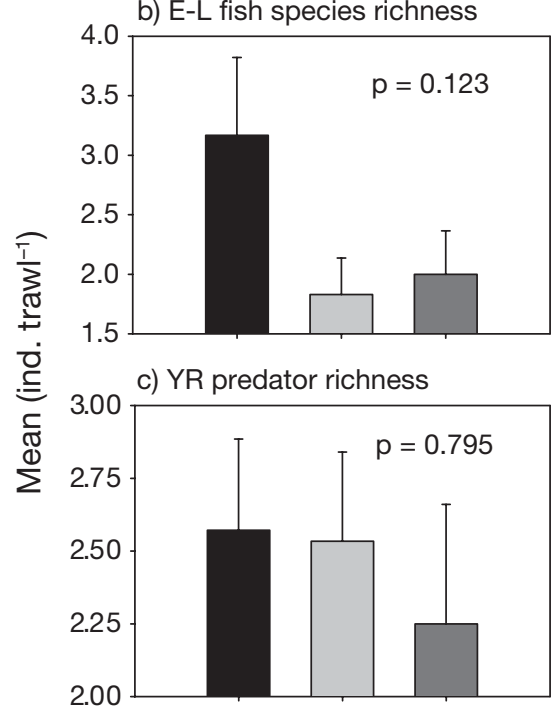

d) YR fish species richness

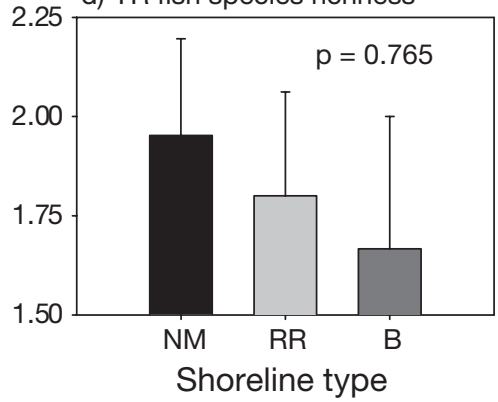

Fig. 13. Mean (+SE) species richness of predators in shallow subtidal habitats adjacent to natural marsh (NM), rip-rap (RR) or bulkhead (B) shorelines for (a) all predators and (b) fish in the Elizabeth-Lafayette (E-L) River system, (c) all predators and (d) fish in the York River (YR). ANOVA p-values are given

dulatus), which prey heavily on larger bivalves and polychaetes. Furthermore, whether considering a somewhat degraded river system such as the E-L or a relatively unstressed system such as the YR, the shallows emerged as a prime habitat for bivalves and other long-lived benthic infauna. Consequently, shallowwater habitats are important in providing food resources to upper trophic levels, and they are highly deserving of conservation and restoration efforts (Peterson \& Lipcius 2003). The results obtained for these tributaries are likely to be found in other Chesa- peake Bay tributaries, and shallow-water habitats in general. Other bay tributaries, such as the Rhode River in Maryland, have similarly high densities of bivalves in the shallow habitats of $<4 \mathrm{~m}$ depth (Seitz et al. 2001) and this pattern should be representative of shallow habitats throughout the Chesapeake Bay.

The patterns in bivalve biomass and abundance may have been produced by any one of several mechanisms. Physical variables that may favor an increased abundance and biomass in the shallows include sediment grain size, temperature, or dissolved oxygen. Sediment grain size is a primary determinant of benthic community structure, which is enhanced where the grain size is not extremely fine or coarse (Holland 1985, Schaffner et al. 2002). In our study, bivalve biomass was higher where the sand fraction was higher, in shallow habitats. Though salinity can control benthic densities in shallow waters (Holland 1985), the differences in salinity between deep and shallow habitats in our study were minor; we therefore conclude that salinity did not affect infaunal densities within strata more than did sediment type. Though hypoxia was not observed during our sampling in September 2002, it may have been prevalent in deep habitats in the preceding summer (as was noted for YR deep habitats in June 2003; R. Seitz \& W. Long unpubl. data), leading to the lower density and biomass of adult bivalves in deep habitats, as seen in the YR (Boesch \& Rosenberg 1981) and Chesapeake Bay (Kemp et al. 2005).

Higher abundance and biomass in the shallows could also be due to increased food (e.g. benthic macroalgae) for benthic deposit-feeders (Kneib et al. 1980); shallow waters may allow decreased watercolumn degradation of carbon sources and quicker delivery of high-quality food to the benthos. Shallow areas may also experience an increased subsidy of allochthonous carbon from runoff through productive salt marshes. Bottom-up control of benthic organisms has been documented for various systems (Crowder et al. 1988, McQueen et al. 1989, Menge \& Olson 1990, Menge et al. 1997, Posey et al. 2005) including Chesapeake Bay (Seitz et al. 2003b). In addition, lower densities of infaunal organisms in deep habitats could be a result of human impacts, as anthropogenic low dissolved oxygen in deep channels may lead to a reduction of infauna at depth (Dauer et al. 2000, Zimmerman 2000, Kemp et al. 2005).

The observed patterns and results of this study must be interpreted within the limitations of the timing of the study. For instance, we examined a single 'snapshot' in time in the fall, after the majority of predation upon the benthos had occurred. Thus, the impact of seasonality on bivalve abundance patterns remains uncertain. However, the presence of large, long-lived bivalves such as Macoma balthica in shallow habitats 
and their absence in the deeper habitats indicates that the findings would not be likely to change qualitatively in different seasons. The results further suggest that in deep habitats, juveniles of dominant benthic species such as $M$. balthica either do not recruit, suffer high mortality, or emigrate to other habitats. We would expect the magnitude of abundance to change seasonally, particularly during spring recruitment periods, but our conclusions regarding the comparative benthic abundance, biomass, and diversity in shallow and deep habitats should not change qualitatively were we to repeat the study during other seasons. We are currently continuing these studies to examine temporal variation in these systems, and the spatial generality of the findings to other systems.

\section{Effects of shoreline development upon benthic abundance and diversity}

Benthic bivalve density and diversity were greatest adjacent to natural marsh habitats compared to rip-rap or bulkhead shorelines in the E-L River system, and infaunal density and diversity were highest in natural marsh and rip-rap as compared to bulkhead in the YR system. The E-L River system is a waterway within the city of Norfolk, which is 'an urban, highly developed region... with land use dominated by high-density residential districts, commercial and industrial developments, and military reservations... [where] heavy industrial, military, commercial, and residential development prevail... few shoreline miles remain unaltered' (Berman et al. 2002). In the E-L River system, which has over $50 \%$ of its shoreline developed (Berman et al. 2002), the pattern of high density adjacent to natural marsh habitats was significant for density of some bivalve species (e.g. Macoma balthica), but not for others (e.g. Tagelus plebeius).

We suggest that developed shorelines have negative impacts on benthic infauna in subtidal habitats adjacent to the shoreline, and not just to shoreline habitats such as salt marshes themselves (Carroll 2003). This may arise because the allochthonous input of carbon from marsh materials may be an important food source (Currin et al. 1995, French McCay \& Rowe 2003), particularly for deposit-feeding infauna (e.g. Macoma balthica), and this input is reduced where shorelines are developed with an impermeable bulkhead. This idea is supported by the trend of slightly increased water clarity in our bulkhead sites compared to natural marsh sites in the YR. This may also explain why organisms that are not deposit feeders (e.g. the suspension-feeding Tagelus plebeius in the E-L River system) were not affected by shoreline type, since they may rely on water-column food sources that are inte- grated from water that has passed over distant habitats. Another explanation could be that hydrodynamics are changed by the alteration of the shoreline such that higher current flow impedes settlement of some benthic organisms. This explanation is not supported by our sediment grain size comparison that showed no significant differences among shoreline types. The only other study of which we are aware that demonstrates negative effects of shoreline development upon the subtidal benthic community was one that examined the impact of toxics in CCA-treated wooden bulkheads (Weis et al. 1998). Such a negative impact of chemically treated wood could partially explain the results found in our study; however, only some of the bulkhead shorelines we studied used treated wood, whereas others used metal or concrete.

In the YR, a less-developed and larger system than the E-L system, bivalve prey abundance and benthic community diversity were greater in both natural marsh and rip-rap than in bulkhead habitats. The YR has approximately $86 \%$ of the distance along its shoreline as natural marsh, whereas about $6 \%$ is developed (rip-rap, bulkhead, groin or miscellaneous including tires, concrete or railroad ties) and $\sim 8 \%$ is upland such as beaches (Berman et al. 1999). We hypothesize that the YR system has much larger expanses of unaltered marsh habitat available to subsidize adjacent developed shorelines; rip-rap shorelines tend to be surrounded by natural marsh habitats, and therefore riprap habitats in the YR are not as negatively influenced by development as those in heavily developed systems such as the E-L River system.

A handful of studies have looked at the impacts of shoreline structures on predators alone. One study suggested moderate impacts of rip-rap shorelines compared to natural marsh on nekton; abundances of juvenile crabs were decreased in rip-rap compared to natural marsh habitats (Carroll 2003). Moreover, fish and crabs were least abundant along shorelines altered with bulkheads or rubble and most abundant along marsh habitats (Peterson et al. 2000). Diversity of those predators was lower adjacent to altered marshes than adjacent to natural marshes. In an additional study, abundance of gobies was significantly higher in waters adjacent to unaltered marsh than adjacent to altered habitats (Hendon et al. 2000). The authors suggested that these reductions were due to reduced habitat suitability for these benthic fish.

Several studies have examined nekton and benthos within the marsh, but these studies did not venture further than $1 \mathrm{~m}$ from the marsh edge (e.g. Whaley \& Minello 2002). A few months after marsh establishment, macroinfaunal abundance was greater in natural marshes than created marshes in Galveston, Texas (Minello \& Webb 1997). However, after 1 yr, created 
marshes apparently reached their maximum support potential for nekton, and densities were similar between natural and created marshes (Minello 2001). Moreover, benthic infauna may serve as prey for many marsh predators (e.g. juvenile fishery species) that aggregate near the marsh edge (Whaley \& Minello 2002). Because of the high productivity of marshes, they have been proposed as one of the nearshore ecosystems serving as a nursery for many fish and invertebrates (Beck et al. 2001). A meta-analysis of the nursery role hypothesis for marshes indicated that marshes serve as nurseries for nekton (decapod crustaceans and fishes); thus, these species are likely to be adversely affected by marsh depletion (Minello et al. 2003).

In our study, density and diversity of epibenthic predators (e.g. spot, croaker, hogchoker and blue crab) tended to mirror prey densities, with a trend towards higher density and diversity in natural marsh than in bulkhead shorelines (with significantly higher densities of crabs next to natural marsh in both systems combined). The generally similar pattern of predator and prey densities in relation to shoreline type in both systems suggests that there is a functional relationship between predators and prey whereby predators may be concentrating in habitats with elevated prey densities, and where food is therefore abundant (i.e. bottomup control). Evidence for bottom-up control of the blue crab by its principal prey (i.e. thin-shelled clams) in the YR has been documented (Seitz et al. 2003b), and the results of this study support previous findings. Although elevated densities of prey and predators in shallow habitats may have been caused by an independent factor (e.g. sediment type or hydrodynamics), we suggest that reduced infaunal densities adjacent to bulkhead shorelines diminished predator densities and likely diminished corresponding production of the system. Given the extent of shoreline development in populated coastal areas, this loss of ecosystem services (Peterson \& Lipcius 2003) could have a major impact on overall productivity in estuaries such as Chesapeake Bay.

Our study was conducted in a drought year (2002) when there was minimal runoff into the system. Typically, salt marshes buffer shallow waters from surface runoff and may thereby reduce toxic inputs. During this drought year, the differences we detected between natural marsh and developed shorelines may have been minimal since little buffering was required. In high-runoff years, rip-rap and bulkhead shorelines may allow direct deposition of polluted water (unfiltered by the marsh system), and may have a substantially greater impact on benthic communities.

The higher abundance, biomass, and diversity of bivalves, and possibly that of other long-lived benthic infauna, in shallow habitats has critical implications for food web dynamics and the restoration of degraded estuaries such as Chesapeake Bay (Kemp et al. 2005). Future efforts must be directed at discerning the role of the elevated shallow-water benthic prey biomass in ecosystem processes (e.g. filtration, buffering), in energy flow through the food web, and in the dynamics of lower and higher trophic levels. Moreover, a key link exists between salt marsh habitat, food availability for predators, and predator abundance. Consequently, protection and restoration of salt marsh habitats may be essential to the maintenance of high benthic production and consumer biomass in estuarine ecosystems.

Acknowledgements. We thank the staff and students at the Virginia Institute of Marine Science who helped with this project including K. Delano, M. Montane, W. C. Long, T. Childress, S. Gera and Captain C. Machen. The manuscript was significantly improved by constructive comments from R. Diaz, D. Dauer, W. C. Long, J. Long, and 2 anonymous reviewers. Funding was provided by the Army Corps of Engineers, by the Chesapeake Bay Restoration Fund, by the National Science Foundation Research Experiences for Undergraduates Program, by Virginia Sea Grant, by the Essential Fish Habitat Program of the National Sea Grant Office, by the Governor's School Program of the Commonwealth of Virginia, and by a grant to the Blue Crab Advanced Research Consortium from the National Oceanic and Atmospheric Administration's Chesapeake Bay Office. This is contribution number 2745 from the Virginia Institute of Marine Science.

\section{LITERATURE CITED}

Baird D, Ulanowicz RE (1989) Seasonal dynamics of the Chesapeake Bay ecosystem. Ecol Monogr 59:329-364

Beck MW, Heck KL Jr, Able KW, Childers DL and 9 others (2001) The identification, conservation, and management of estuarine and marine nurseries for fish and invertebrates. Bioscience 51:633-641

Berman M, Berquist H, Dewing S, Thoman G, Laird R (1999) Gloucester county shoreline and tidal marsh inventory. Special Report in Applied Marine Science and Ocean Engineering, No. 351 Virginia Institute of Marine Science, Gloucester Point, VA. RMAP.99.003.1

Berman M, Berquist H, Hershner C, Killeen S, Rudnicky T, Schatt D, Weiss D, Woods H (2002) City of Norfolkshoreline situation report. Special report in Applied Marine Science and Ocean Engineering, No. 378 Virginia Institute of Marine Science, Gloucester Point, VA

Bernstein C, Auger P, Poggiale JC (1999) Predator migration decisions, the ideal free distribution, and predator-prey dynamics. Am Nat 153:267-281

Beukema JJ (1993) Successive changes in distribution patterns as an adaptive strategy in the bivalve Macoma balthica (L.) in the Wadden Sea. Helgol Meeresunters 47: 287-304

Boesch DF (1977) A new look at the zonation of benthos along the estuarine gradient. In: Coull BC (ed) Ecology of marine benthos. Belle W. Baruch Marine Library in Marine Science, Vol 6. University of South Carolina Press, Columbia, SC, p 245-266 
Boesch DF, Rosenberg R (1981) Response to stress in marine benthic communities. In: Barrett GW, Rosenberg R (eds) Stress effects on natural ecosystems. Wiley, New York, p $179-200$

Carroll R (2003) Nekton utilization of intertidal fringing salt marsh and revetment hardened shorelines. Masters thesis, The College of William and Mary, Virginia Institute of Marine Science, Gloucester Point, VA

Cicchetti G (1998) Habitat use, secondary production and trophic export by salt marsh nekton in shallow waters. PhD dissertation, The College of William and Mary, Virginia Institute of Marine Science, Gloucester Point, VA

Cicchetti G, Diaz RJ (2000) Types of salt marsh edge and export of trophic energy from marshes to deeper habitats. In: Weinstein MP, Kreeger DA (eds) Concepts and controversies in tidal marsh ecology. Kluwer Academic Publishers, Dordrecht, p 515-542

Clark KR, Gorley RN (2001) Primer v5, user manual. Plymouth Marine Laboratory, Plymouth

Clarke KR, Warwick RM (2001) Change in marine communities: an approach to statistical analysis and interpretation, 2nd edn. Plymouth Marine Laboratory, Plymouth

Clark RD, Christensen JD, Monaco ME, Caldwell PA, Matthews GA, Minello TJ (2004) A habitat-use model to determine essential fish habitat for juvenile brown shrimp (Farfantepenaeus aztecus) in Galveston Bay, Texas. Fish Bull 102:264-277

Connell JH (1978) Diversity in tropical rain forests and coral reefs. Science 199:1302-1310

Crowder LB, Drenner RW, Kerfoot C, McQueen DJ, Mills EL, Sommer U, Spencer CN (1988) Food web interactions in lakes. In: Carpenter SR (ed) Complex interactions in lake communities. Springer-Verlag, New York, p 141-160

Currin CA, Newell SY, Pearl HW (1995) The role of standing dead Spartina alterniflora and benthic microalgae in salt marsh food webs: considerations based on multiple isotope analysis. Mar Ecol Prog Ser 121:99-116

Dauer DM (2001) Benthic biological monitoring program of the Elizabeth River watershed (2000). Report for Virginia Department of Environmental Quality. Old Dominion University, Norfolk, VA

Dauer DM, Alden RW (1995) Long-term trends in the macrobenthos and water quality of the lower Chesapeake Bay (1985-1991). Mar Pollut Bull 30:840-850

Dauer DM, Ewing RM, Rodi AJ (1987) Macrobenthic distribution within the sediment along an estuarine salinity gradient. Int Rev Gesamten Hydrobiol 72:529-538

Dauer DM, Weisberg SB, Ranasinghe JA (2000) Relationships between benthic community condition, water quality, sediment quality, nutrient loads, and land use patterns in Chesapeake Bay. Estuaries 23:80-96

Delano K (2004) Variation in reproductive output of the Baltic clam, Macoma balthica, in shallow systems of the Chesapeake Bay: habitat type and spatial scale. Masters thesis, The College of William and Mary, Virginia Institute of Marine Science, Gloucester Point, VA

Diaz RJ, Schaffner LC (1990) The functional role of estuarine benthos. In: Haire M, Krome EC (eds) Perspectives on the Chesapeake Bay, 1990. Advances in estuarine sciences, Report no. CBP/TRS41/90. Chesapeake Research Consortium, Gloucester Point, VA, p 25-56

Eggleston DB, Lipcius RN, Hines AH (1992) Densitydependent predation by blue crabs upon infaunal clam species with contrasting distribution and abundance patterns. Mar Ecol Prog Ser 85:55-68

Folk RL (1980) Petrology of sedimentary rocks. Hemphill Publishing, Austin, TX
French McCay DF, Rowe JJ (2003) Habitat restoration as mitigation for lost production at multiple trophic levels. Mar Ecol Prog Ser 264:233-247

Gray JS (2000) The measurement of marine species diversity, with an application to the benthic fauna of the Norwegian continental shelf. J Exp Mar Biol Ecol 250:23-49

Hagy JD (2002) Eutrophication, hypoxia, and trophic tranfer efficiency in Chesapeake Bay. PhD dissertation, University of Maryland, Center for Environmental Science, Solomons, MD

Hawthorne SD, Dauer DM (1983) Macrobenthic communities of the Chesapeake Bay. III. Southern branch of the Elizabeth River. Int Rev Gesamten Hydrobiol 68:193-205

Hendon JR, Peterson MS, Comyns BH (2000) Spatio-temporal distribution of larval Gobiosoma bosc in waters adjacent to natural and altered marsh-edge habitats of Mississippi coastal waters. Bull Mar Sci 66:143-156

Hines AH, Comtois KL (1985) Vertical distribution of infauna in sediments of a subestuary of central Chesapeake Bay. Estuaries 8:296-304

Hines AH, Haddon AM, Wiechert LA (1990) Guild structure and foraging impact of blue crabs and epibenthic fish in a subestuary of Chesapeake Bay. Mar Ecol Prog Ser 67: $105-126$

Holland AF (1985) Long-term variation in macrobenthos in the mesohaline region of Chesapeake Bay. Estuaries 8:93-113

Horwitz RJ (1987) Fish. In: Heck KL (ed) Ecological studies in the middle reach of Chesapeake Bay, Calvert Cliffs, Vol 23. Lecture notes on coastal and estuarine studies. Springer-Verlag, New York, p 167-225

Jackson JBC (1972) The ecology of the molluscs of Thalassia communities, Jamaica, West Indies. II. Molluscan population variability along an environmental stress gradient. Mar Biol 14:304-337

Jivoff PR, Able KA (2003) Evaluating salt marsh restoration in Delaware Bay: the response of blue crabs, Callinectes sapidus, at former salt hay farms. Estuaries 26:709-719

Kemp WM, Boynton WR, Adolf JE, Boesch DF and 14 others (2005) Eutrophication of Chesapeake Bay: historical trends and ecological interactions. Mar Ecol Prog Ser 303: $1-29$

King RS, Hines AH, Craige FD, Grap S (2005) Regional, watershed, and local correlates of blue crab and bivalve abundances in subestuaries of Chesapeake Bay, USA. J Exp Mar Biol Ecol 319:101-116

Kneib RT (1997) The role of tidal marshes in the ecology of estuarine nekton. Ocean Mar Biol Ann Rev 35:163-220

Kneib RT, Stiven AE, Haines EB (1980) Stable carbon isotope ratios in Fundulus heteroclitus (L.) on a North Carolina salt marsh. J Exp Mar Biol Ecol 46:89-98

Laughlin RA (1982) Feeding habits of the blue crab, Callinectes sapidus Rathbun, in the Apalachicola estuary, Florida. Bull Mar Sci 32:807-822

Mansour RA (1992) Foraging ecology of the blue crab, Callinectes sapidus Rathbun, in lower Chesapeake Bay. $\mathrm{PhD}$ dissertation, The College of William and Mary, Virginia Institute of Marine Science, Gloucester Point, VA

Mansour RA, Lipcius RN (1991) Density-dependent foraging and mutual interference in blue crabs preying upon infaunal clams. Mar Ecol Prog Ser 72:239-246

McQueen DJ, Johannes MRS, Post JR, Steward TJ, Lean DRS (1989) Bottom-up and top-down impacts on freshwater pelagic community structure. Ecol Monogr 59:289-309

Menge BA, Olson AM (1990) Role of scale and environmental factors in regulation of community structure. Trends Ecol Evol 5:52-57

Menge BA, Daley B, Wheeler PA (1996) Control of interaction 
strength in marine benthic communities. In: Polis GA, Winemiller KO (eds), Food webs: integration of pattern and dynamics. Chapman \& Hall, New York, p 258-274

Menge BA, Daley B, Wheeler PA, Strub PT (1997) Rocky intertidal oceanography: an association between community structure and nearshore phytoplankton concentration. Limnol Oceanogr 42:57-66

Minello TJ (2001) Temporal development of salt marsh value for nekton and epifauna: utilization of dredged material marshes in Galveston Bay, Texas, USA. Wetlands Ecol Manag 8:327-341

Minello TJ, Webb JW Jr (1997) Use of natural and created Spartina alterniflora salt marshes by fishery species and other aquatic fauna in Galveston Bay, Texas, USA. Mar Ecol Prog Ser 151:165-179

Minello TJ, Able KW, Weinstein MP, Hays CG (2003) Salt marshes as nurseries for nekton: testing hypotheses on density, growth and survival through meta-analysis. Mar Ecol Prog Ser 246:39-59

Paine RT (1966) Food web complexity and species diversity. Am Nat 100:65-75

Peterson CH, Lipcius RN (2003) Conceptual progress towards predicting quantitative ecosystem benefits of ecological restorations. Mar Ecol Prog Ser 264:297-307

Peterson MS, Comyns BH, Hendon JR, Bond PJ, Duff GA (2000) Habitat use by early life-history stages of fishes and crustaceans along a changing estuarine landscape: Differences between natural and altered shoreline sites. Wetlands Ecol Manag 8:209-219

Posey M, Powell C, Cahoon L, Lindquist D (1995) Top down vs. bottom up control of benthic community composition on an intertidal tideflat. J Exp Mar Biol Ecol 185:19-31

Rex MA, Stuart CT, Hessler RR, Allen JA, Sanders HL, Wilson GDF (1993) Global-scale latitudinal patterns of species diversity in deep sea benthos. Nature 65:636-639

Schaffner LC, Friedrichs CT, Dauer DM (2002) Review of the benthic process model with recommendation for future modeling efforts. A report from the benthic process model review team. Virginia Institute of Marine Science, Gloucester Point, VA

Seitz RD, Lipcius RN, Hines AH, Eggleston DB (2001) Density-dependent predation, habitat variation, and the persistence of marine bivalve prey. Ecology 82:2435-2451

Seitz RD, Marshall LS Jr, Hines AH, Clark KL (2003a) Effects

Editorial responsibility: Otto Kinne (Editor-in-Chief),

Oldendorf/Luhe, Germany of hypoxia on predator-prey dynamics of the blue crab Callinectes sapidus and the Baltic clam Macoma balthica in Chesapeake Bay. Mar Ecol Prog Ser 257:179-188

Seitz RD, Lipcius RN, Stockhausen WT, Delano KA, Seebo MS, Gerdes PD (2003b) Potential bottom-up control of blue crab (Callinectes sapidus) distribution at broad spatial scales. Bull Mar Sci 72:471-490

Seneca ED, Broome SW (1992) Restoring tidal marshes in North Carolina and France. In: Thayer GW (ed) Restoring the nation's marine environment. Maryland Sea Grant, College Park, MD, p 53-73

Sih A, Crowley P, McPeek M, Petranka J, Strohmeier K (1985) Predation, competition, and prey communities: a review of field experiments. Ann Rev Ecol Syst 16:269-311

Thayer GW (1992) (ed) Restoring the nation's marine environment. Maryland Sea Grant, College Park, MD

Tourtellotte GH, Dauer DM (1983) Macrobenthic communities of the Chesapeake Bay. II. Lynnhaven Roads, Lynnhaven Bay, Broad Bay, Linkhorn Bay. Int Rev Gesamten Hydrobiol 68:59-72

Virnstein RW (1977) The importance of predation by blue crabs and fishes on benthic infauna in Chesapeake Bay. Ecology 58:1199-1217

Virnstein RW, Nelson WG, Nelson FG III, Howard RK (1984) Latitudinal patterns in seagrass epifauna: Do patterns exist, and can they be explained? Estuaries 7:310-330

Weis JS, Weis P, Proctor T (1998) The extent of benthic impacts of CCA-treated wood structures in Atlantic coast estuaries. Arch Environ Contam Toxicol 34:313-322

Weisberg SB, Ranasinghe JA, Dauer DM, Schaffner LC, Diaz RJ, Frithsen JB (1997) An estuarine benthic index of biotic integrity (B-IBI) for Chesapeake Bay. Estuaries 20:149-158

Whaley, SD, Minello TJ (2002) The distribution of benthic infauna of a Texas salt marsh in relation to the marsh edge. Wetlands 22:753-766

Zedler JB (1992) Restoring cordgrass marshes in Southern California. In: Thayer GW (ed) Restoring the nation's marine environment. Maryland Sea Grant, College Park, $\mathrm{MD}, \mathrm{p} 7-41$

Zimmerman AR (2000) Organic matter composition of sediments and the history of eutrophication and anoxia in the mesohaline Chesapeake Bay. PhD dissertation, College of William and Mary, Virginia Institute of Marine Science, Gloucester Point, VA

Submitted: March 1, 2005; Accepted: May 2, 2006

Proofs received from author(s): November 9, 2006 